\title{
COMPORTAMENTO DE CULTIVARES DE CANA-DE-AÇÚCAR EM FUNÇÃO DO SOLO E DA ÉPOCA DE COLHEITA
}

\author{
RODRIGO FERNANDO MAULE \\ Engenheiro Agrônomo
}

Orientador: Prof. Dr. JAIRO A. MAZZA

Dissertação apresentada à Escola Superior de Agricultura "Luiz de Queiroz", Universidade de São Paulo, para obtenção do titulo de Mestre em Agronomia, Área de Concentração: Solos e Nutrição de Plantas.

PIRACICABA

Estado de São Paulo - Brasil

Agosto - 1999 
Dados Internacionais de Catalogação na Publicação (CIP) DIVISÃo DE BIBLIOTECA E DOCUMENTAÇÃO - Campus "Luiz de Queiroz"/USP

\author{
Maule, Rodrigo Fernando \\ Comportamento de cultivares de cana-de-açúcar em função do solo e da época de \\ colheita / Rodrigo Fernando Maule. - - Piracicaba, 1999. \\ 57 p. : il. \\ Dissertaçāo (mestrado) - - Escola Superior de Agricultura Luiz de Queiroz, 1999. \\ Bibliografia. \\ 1. Cana-de-açúcar 2. Época de colheita 3. Maturação 4. Produção agricola 5. \\ Solo 6. Variedade I. Título
}

CDD 633.61 
Aos meus pais,

Bruno e Maria Luiza

por terem indicado os caminhos da vida.

\section{Dedico}

À amada Juliana,

pelos momentos de compreensão e apoio

Ofereço 


\section{AGRADECIMENTOS}

Ao Prof. Dr.Jairo A. Mazza, pela amizade e pela contribuição à minha formação como profissional e como pessoa.

À minha familia, pelo apóio e incentivo para vencer mais uma etapa da vida.

Ao Prof. Dr. Luís R. F. Alleoni e Dr. Marcelo de Almeida Silva pelas discussões e auxílio para finalização deste trabalho.

Aos amigos Boy, Ênio, Michel, Dany, Nani, Peterson, Simone, Hamilton, Marcos e a todos os colegas que cruzaram meu caminho, pela amizade e pelo respeito.

Ao Departamento de Solos e Nutrição de Plantas da Escola Superior de Agricultura "Luiz de Queiroz", por ter possibilitado a execução deste trabalho e a CAPES, pela concessão da bolsa de estudo.

Aos funcionários, Vladimir, Luciano, Eduardo, Lico, Flávia do Departamento de Solos e Nutrição de Plantas da Escola Superior de Agricultura "Luiz de Queiroz". pela amizade e auxílio nas análises deste trabalho.

À Sra Eliana M. G. Sabino, pela gentileza de conferir a normatização das citações de literatura e à toda equipe da Biblioteca Central da ESALQ/USP pelo profissionalismo e boa vontade.

Ao Eng. Agro. Marcelo C. Alves pelo auxílio na parte estatística deste traballho.

Ao pesquisadores da UFSCAR, pelos conselhos e fornecimento do material genético utilizado neste trabalho.

À Ecal, pelo patrocínio financeiro para execução das análises.

À todos que de alguma forma contribuíram para que esse trabalho se tornasse realidade. 


\section{SUMÁRIO}

Página

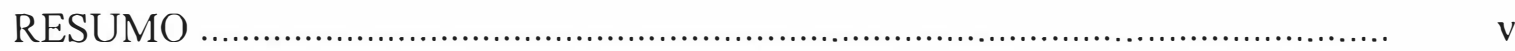

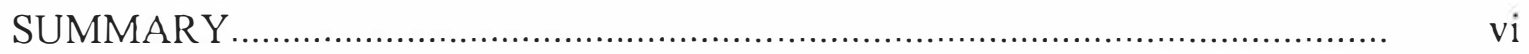

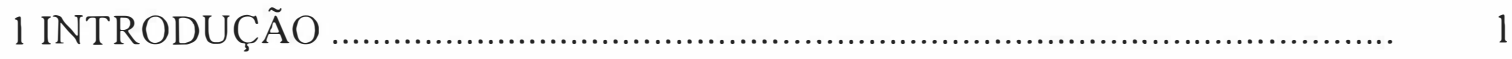

2 REVISÃO DE LITERATURA …............................................................ 3

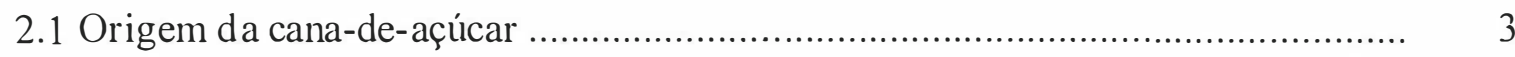

2.2 Importância e distribuição da cana-de-açúcar no Brasil...................... 3

2.3 Zoneamento edafo-climático e adaptação ecológica da cana-de-

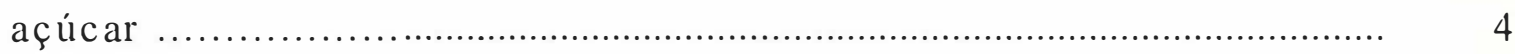

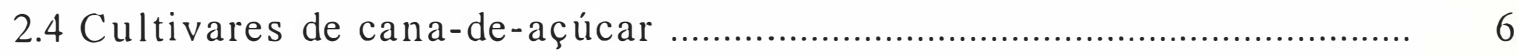

2.5 Interações das cultivares de cana-de-açúcar com o ambiente ........... 7

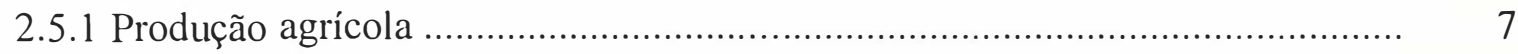

2.5.2 Potencial de produção de açúcar ............................................................ 10

3 MATERIAL E MÉTODOS ................................................................... 13

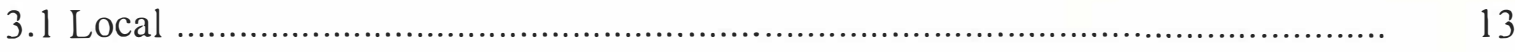

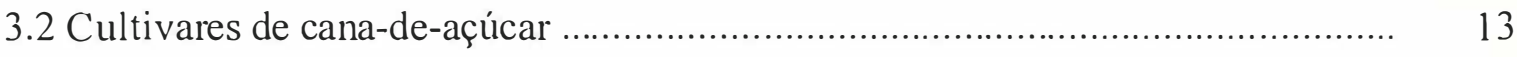

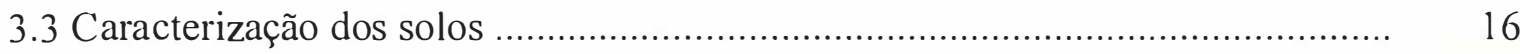

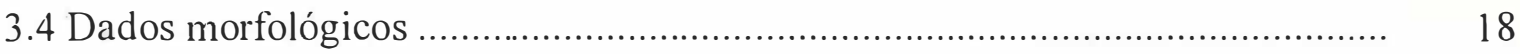

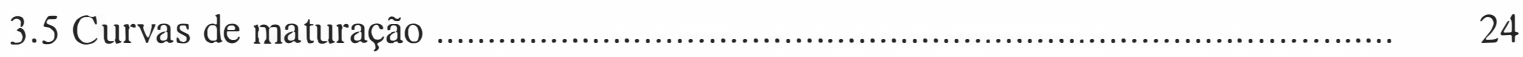

3.6 Delineamento do experimento de produção agrícola ...................................... 24

4 RESULTADOS E DISCUSSÃO ........................................................ 26

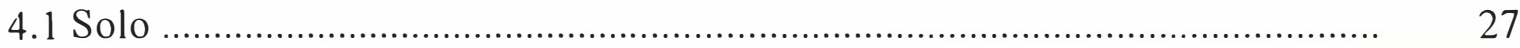

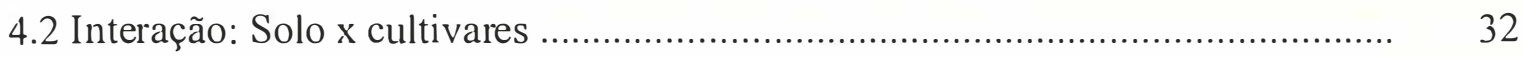

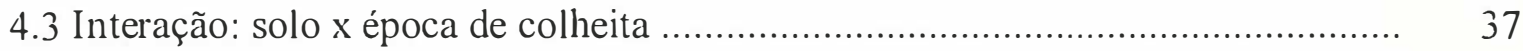

4.4 Interação: época de colheita $x$ cultivares ....................................................... 40

4.5 Influência do ambiente na produção agrícola da cana-de-açúcar ......................... 42 
Página

4.6 Comportamento das características tecnológicas das cultivares em função do ambiente

5 CONCLUSÕES

REFERÊNCIAS BIBLIOGRÁFICAS 


\title{
COMPORTAMENTO DE CULTIVARES DE CANA-DE-AÇÚCAR EM FUNÇÃO DO SOLO E DA ÉPOCA DE COLHEITA
}

\author{
Autor: Rodrigo Fernando Maule \\ Orientador: Jairo Antônio Mazza
}

\section{RESUMO}

A cultura da cana-de-açúcar é destaque no cenário agrícola do Brasil e ocupa vários tipos de ambiente (associação de clima e solo). O estudo das respostas dos diferentes cultivares em cada ambiente de produção, auxilia a maximizar a exploração econômica da cultura.

Neste contexto, três experimentos em blocos completos casualizados com quatro repetições foram delineados para determinar a produtividade de colmos e a produtividade potencial de açúcar de nove cultivares de cana-de-açúcar em dois solos, Planossolo mesotrófico textura arenosa/média (PL) e Podzólico Vermelho Amarelo mesotrófico textura arenosa/média (PV). As cultivares foram colhidas em três épocas Maio, Agosto e Outubro de 1997. A análise de variância seguiu o esquema de análise conjunta de experimentos.

$\mathrm{Na}$ colheita de Maio observaram-se maiores produtividades de colmos no PV, enquanto que no PL, as maiores produtividades de colmos foram observadas em Outubro. Por outro lado, as produtividades de colmos foram superiores $(\mathrm{P}<0,01)$ no $\mathrm{PV}$, em comparação ao PL, e, este fato foi consequência das diferentes condições hídricas entre os dois solos. Em ambos os solos o maior potencial de produtividade de açúcar foi verificado na terceira época (Outubro), enfatizando o papel do ambiente (solo e época de colheita) na produtividade de colmos e na produtividade potencial de açúcar de cultivares da cana-de-açúcar. 


\section{GROWTH OF SUGARCANE CULTIVARS AS A FUNCTION OF SOIL TYPE AND HARVEST PERIOD}

Author: Rodrigo Fernando Maule

Adviser: Jairo Antônio Mazza

\section{SUMMARY}

Sugarcane is one of the most important crops of the Brazilian agriculture and it is distributed over a large range of environments (climate and soil). The study of different cultivars in different environments helps to improve and maximize the overall stalk and sugar productivities.

In this context, three experiments were performed to assess differences in stalk weight and potential sugar productivity of nine sugarcane cultivars which were grown in two soils, aqult (PL) and udult (PV), both Ultisols. The experiments were harvested on three different months (May. August and October), and a randomized block design with four replicates was used. The data was arranged to all experiments, which was used to perform the overall analysis of variance.

Higher stalk weights at the PV soil were observed at the May harvest where as the PL soil had higher stalk weight in October. However, sugarcane cultivars. grown in the PV soil had higher stalk weight $(P<0.01)$ than plants of the PL soil. This reflects the differences in water holding capacity of the two soils. Cultivars grown in both soils showed higher potential sugar productivity in the third harvest (October), emphasizing the role of environment (soil and period of harvesting) on stalk.weight and potential sugar productivities of the nine sugarcane cultivars used. 


\section{INTRODUÇÃO}

A crescente preocupação da sociedade mundial com o meı ambiente vem gerando pressão sobre o uso de combustíveis fósseis, os quais são os grandes responsáveis pela emissão de gases poluentes na atmosfera. Vários países estão buscando reduzir ao máximo o uso desses combustíveis, seja pela substituição do produto ou pela adição de outros combustíveis para diminuir a carga poluidora.

A cultura da cana-de-açúcar (Saccharum spp.) tem um enorme potencial para produção de álcool, além de outros produtos usados na indústria química e na geração de energia elétrica. Atualmente, a cana-de-açúcar é uma das melhores opções dentre as fontes de energia renováveis, apresentando grande importância no cenário agrícola brasileiro e um futuro promissor no cenário mundial.

As agroindústrias do setor canavieiro promovem o processamento da cana-deaçúcar por um período relativamente longo, necessitando de matéria prima com a melhor

qualidade possível, pois isso, aumenta muito a eficiência nos processos envolvidos na obtenção dos produtos gerados a partir desta cultura. Para atender todo este período de safra com material de qualidade, existe hoje uma enorme disponibilidade de cultivares com características diferentes, graças ao sistema de melhoramento de plantas desse setor.

Vários fatores interferem na produção e qualidade da cultura da cana-de-açúcar, sendo os principais: a interação edafoclimática, o manejo adotado da cultura e a cultivar escolhida.

A escolha correta das cultivares de cana-de-açúcar e o escalonamento de colheita através de um manejo adequado deve amenizar as interferências de natureza quantitativa e qualitativa que alteram a produção e qualidade da cultura da cana-de-açúcar. 
Como o Brasil é um dos mais tradicionais produtores de cana-de-açúcar e possui grande extensão territorial, a cana-de-açúcar é cultivada em vários tipos de solos que estão sob influência de diferentes climas, o que gera vários tipos de ambiente para produção desta cultura.

Esses fatores que interferem na produção e qualidade da cana-de-açúcar estão sendo constantemente estudados sob diferentes aspectos. Estudar a cultura no seu ambiente de desenvolvimento pode gerar uma enorme quantidade de informações para adequar o melhor manejo e cultivar para os específicos ambientes (solo e clima). Assim é possível explorar ao máximo o local de produção para promover o melhor rendimento da cultura e conseqüente maior lucratividade ou competitividade para as agroindústrias da cana-de-açúcar.

Este trabalho tem como objetivo mostrar a variação da produção agrícola e as mudanças nas características tecnológicas das cultivares de cana-de-açúcar estudadas de acordo com o ambiente de produção, onde a cultura está inserida, mostrando a importância do escalonamento de colheita e local de plantio das cultivares para uma indústria sucroalcooleira. 


\section{REVISÃO DE LITERATURA}

\subsection{Origem da cana-de-açúcar}

A cana-de-açúcar engloba as canas "nobres" ou "tropicais" e tem como provável região de origem a Oceania (Nova Guiné) (Câmara, 1996).

A cana-de-açúcar foi uma das primeiras culturas introduzidas no Brasil para exploração comercial. A Coroa Portuguesa, com a preocupação de garantir posse das terras recém descobertas, optou pelo cultivo da cana-de-açúcar como uma maneira viável de fixar colonos no Brasil, pois na época o mercado de açúcar encontrava-se em franca atividade e expansão na Europa (Câmara, 1996; Lucchesi, 1995). Desde então a cultura da cana-de-açúcar vem ocupando destaque no cenário agrícola brasileiro e mundial. Hoje ela é produzida comercialmente em mais de 70 países (Lucchesi, 1995).

\subsection{Importância e distribuição da cana-de-açúcar no Brasil}

A produção nacional de açúcar gira em torno de 13,3 milhões de megagrama $(\mathrm{Mg})$, dos quais 8,1 milhões se destinam ao consumo interno. Já a produção de álcool é da ordem de 13,9 bilhões de litros (Câmara, 1996).

Atualmente a agroindústria canavieira é responsável pela manutenção de milhões de empregos de forma direta ou indireta, ressaltando a grande importância sócioeconômica desta atividade (Stupiello, 1987). Na safra de 1995/1996 a produção de açúcar e álcool se distribuiu em 346 unidades agroindustriais (Câmara. 1996). A canade-açúcar, além de ser a principal fonte de produção de açúcar, é considerada uma das mais viáveis fontes de energia renovável (Bassinello, 1984). Além dos principais 
produtos, açúcar e álcool, a exploração racional da cultura pode gerar uma enorme gama de derivados e subprodutos com valores comerciais, tais como: aglomerados, glutamato monosódico, óleo fúsel, papel, lisina, melaço, etc.

O Brasil é o maior produtor mundial de cana-de-açúcar, ocupando cerca de 4,6 milhões de hectares no território brasileiro. Aproximadamente metade desta área se encontra no Estado de São Paulo, de onde provém cerca de $60 \%$ da produção nacional desta cultura, estimada em cerca de 300 milhões de megagrama (IBGE, 1996). Das terras do Estado de São Paulo 14\% são ocupadas pela cana-de-açúcar (SÃO PAULO, 1997).

\subsection{Zoneamento edafo-climático e adaptação ecológica da cana-de- a çú car}

A produção da cana-de-açúcar pode ocorrer numa ampla faixa de latitude. desde $35^{\circ} \mathrm{N} \mathrm{A} 30^{\circ} \mathrm{S}$ (Magalhães, 1987), sendo cultivada preferencialmente em latitudes entre $15^{\circ} \mathrm{N}$ e $30^{\circ} \mathrm{S}$ (Lucchesi, 1995).

Os fatores ambientais que afetam de maneira marcante a produção da cana-deaçúcar são: temperatura, luz (intensidade e qualidade) e a disponibilidade de água e nutrientes (Magalhães, 1987).

Sendo uma planta gramínea, a cana-de-açúcar desenvolve-se bem em regiões de clima quente. com temperatura oscilando entre $16^{\circ} \mathrm{C}$ e $33^{\circ} \mathrm{C}$ (Fernandes, 1984). Temperaturas inferiores a $21^{\circ} \mathrm{C}$ reduzem a taxa de alongamento dos colmos e promovem o acúmulo de sacarose (Magalhães, 1987). A radiação solar afeta todos os estágios de desenvolvimento da cultura. Assim, quando a cana-de-açúcar se desenvolve sob condições de baixa luminosidade, ela apresenta colmos finos e longos e as plantas apresentam menor acúmulo de matéria seca (Lucchesi, 1995).

A cana-de-açúcar é uma planta com metabolismo fotossintético C4, que responde melhor a elevadas intensidades luminosas. O ponto de saturação de luz é elevado e varia 
dependendo da cultivar (Nickell', citado por Lucchesi. 1995). Mas o principal fator intrínseco à planta responsável pela elevada produção vegetal é o índice de área foliar (IAF), que varia entre as cultivares. A arquitetura foliar da cana-de-açúcar apresenta uma disposição vertical das folhas em relação ao colmo. refletindo em maior capacidade fotossintética, pois proporciona maior incidência da luz no dossel da cultura que possui uma alta densidade populacional (Magalhães, 1987). A cana-de-açúcar, ao atingir seu estágio máximo de desenvolvimento, apresenta, aproximadamente, um índice de área foliar 7, o que corresponde a uma área foliar 7 vezes maior que a área de solo ocupada. Isto confere à cultura uma grande capacidade fotossintética e de troca de substâncias (água, nutrientes e gases) com o ambiente (Fauconnier \& Bassereau. 1975).

Locais de precipitação pluviométrica acima de $1000 \mathrm{~mm}$. bem distribuídos ao longo do ano, são suficientes para garantir o desenvolvimento da cultura da cana-deaçúcar (Fernandes, 1984). Além da distribuição adequada da chuva deve ser ressaltado o potencial de armazenamento de água no solo, que é bastante variado dependendo do tipo e quantidade de porosidade do mesmo. Apesar de o solo ser apenas um dos componentes de um conjunto complexo de fatores de produção, ele destaca-se pelo seu importante papel de fornecer às plantas suporte físico, água e nutrientes. Portanto, o conhecimento das características inerentes a cada solo, os chamados fatores edáficos, é importante para julgar o potencial de produção agrícola (Lepsch. 1987).

A cultura da cana-de-açúcar é cultivada em larga escala dentro do Território Nacional, distribuindo-se em diferentes regiões e ocupando uma grande variabilidade de solos (Favarin, 1995). Como esta cultura é cultivada em diferentes regiões. sob ação de diversos regimes climáticos e ocupando uma grande variedade de solos, estando sujeita a diferentes manejos, se desenvolve nos mais variados ambientes (Dias, 1997).

Para planejar a locação das cultivares de cana-de-açúcar devem ser considerados os fatores de fertilidade natural dos solos, a riqueza em sacarose, o período útil de industrialização, a provável época de colheita e o potencial de produção de colmos (Nunes Junior \& Schouchana, 1984).

\footnotetext{
${ }^{1}$ NICKELL, L.G. Ecophysiology of sugar cane. In: ALVIM, P.T.: KOZLOWSKI. T.T. Ecophysiology of tropical crops. Itabuna: CEPLAC. 1975. p. 1-52.
} 


\subsection{Cultivares de cana-de-açúcar}

As agroindústrias do açúcar se interessam por cultivares de cana-de-açúcar que tenham as seguintes qualidades tecnológicas: alta pureza de caldo, al to teor em sacarose e uma quantidade moderada de fibras (Cesar et al., 1987b). A qualidade tecnológica e o desenvolvimento vegetativo da cana-de-açúcar são influenciados pela cultivar utilizada, época de colheita e o meio em que a cultura está inserida, além do manejo empregado e outros fatores (Cesar et al., 1987b).

Dentro do cenário sucroalcooleiro paulista há três principais programas de melhoramento genético em cana-de-açúcar, sendo que, atualmente, dois são responsáveis pela geração das cultivares que ocupam cerca de $95 \%$ da área plantada com

a cultura (Nunes Junior et al., 1998). Devido à eficiência desses programas de melhoramento, existe hoje uma enorme gama de cultivares à disposição dos produtores.

Desde longa data a interação das plantas com o ambiente (solo, clima, manejo, e outros) é conhecida entre os profissionais ligados à produção vegetal. Os melhoristas de plantas têm como objetivo final desenvolver cultivares basicamente mais produtivas, como resultado de uma maior eficiência fisiológica geral (Allard \& Bradshaw, 1964). Dentro destes programas . ie melhoramento para seleção de novas cultivares de cana-deaçúcar existe uma concordância geral entre os melhoristas de que as interações genótipos $\mathrm{x}$ ambientes têm um importante significado na obtenção de cultivares mais produtivas e de melhor qualidade tecnológica.

Para contornar os problemas causados pelo comportamento diferente das plantas em função do ambiente de trabalho, os melhoristas podem desenvolver cultivares para ambientes especiais, tendo como aspecto negativo, neste caso, grande dispêndio com recursos humanos e financeiros, ou desenvolver cultivares que sejam capazes de controlar seus processos de desenvolvimento, mantendo comportamento consistente frente às variações ambientais (Bassinello, 1984). Os programas de melhoramento passaram a regionalizar os testes com clones nas fases de seleção, para tentar selecionar cultivares de cana-de-açúcar, de ampla adaptação ambiental (Lo, 1987). Apesar desta 
regionalização, ainda se observa variação ambiental dentro das regiões, o que leva à obtenção de cultivares com adaptação satisfatória aos diferentes ambientes de uma região em particular (Raizer, 1998).

\subsection{Interações das cultivares de cana-de-açúcar com o ambiente}

A necessidade atual de se obter alta produtividade agrícola a baixos custos implica em um estudo mais detalhado do ambiente em que a cultura se insere, de forma a maximizar o seu aproveitamento (Beauclair, 1991). A pesquisa de novas técnicas visando à maximização da produção requer, entre outras coisas, uma avaliação prévia dos fatores que influem na produtividade (Butler, 1964).

Diversos fatores interferem no retorno econômico de um canavial, compreendendo desde o momento do preparo do solo até o processo de industrialização da matéria-prima, sempre considerando tudo dentro de um contexto edafoclimático altamente interferente (Nunes Junior \& Schouchana, 1984).

Pollock (1978) citou que vários fatores influenciam as interações de cultivares de cana-de-açúcar com o ambiente, podendo-se apontar: tipo de solo, fertilidade química do solo, quantidade e distribuição das chuvas, temperaturas. práticas culturais, entre outros.

A interação da cultivar com determinadas condições edafoclimáticas determina o rendimento agrícola e a qualidade tecnológica de um canavial.

\subsubsection{Produção agrícola}

A produção agrícola da cana-de-açúcar, em termos de megagramas de colmos por unidade de área, é representado basicamente pelos fatores: número e peso dos colmos (Fernandes, 1986).

As características genéticas inerentes à cada cultivar definem a altura, diâmetro e o número de colmos por planta, além da arquitetura foliar, comprimento e largura das folhas. A expressão destes caracteres é amplamente influenciada pelo clima e manejo empregado na cultura (Magalhães, 1987). As cultivares não apresentam sistemas

radiculares similares, os quais podem apresentar diferentes distribuições dentro de um 
perfil de solo, devido às condições físicas e químicas. além da umidade. encontradas durante o seu desenvolvimento (Humbreit, 1968; Fauconnier \& Bassereau, 1975). A eficiência na absorção de água e nutrientes em um mesmo solo é diferente entre as cultivares de cana-de-açúcar (Humbreit, 1968). Esta eficiência influencia a produção agrícola e depende do clima, da distribuição radicular e das condições edáficas.

Sem dúvida, dentre todas as variáveis envolvidas na produção agrícola, as cultivares ocupam uma posição de destaque, pois estão inter-relacionadas com vários fatores, como o solo, o clima. os insumos, as práticas culturais e a época de plantio e de colheita (Nunes Junior \& Machado Junior, 1981).

Baliero (1995), trabalhando com três cultivares de cana-de-açúcar, constatou que as cultivares apresentaram número de perfillhos variados dependendo da época de colheita anterior, demonstrando, assim, diferentes formas de desenvolvimento das plantas. As cultivares SP71-1406 e SP71-6163 apresentaram o maior perfilhamento quando colhidos em agosto. Já a cultivar RB765418 apresentou o melhor perfillhamento quando colhido em setembro e agosto.

Para a cana-de-açúcar. entende-se por ambiente de produção a junção de uma unidade de mapeamento de solo e uma cultivar em um dado estágio de corte sob um determinado regime climático (precipitação, distribuição das chuvas. evapotranspiração, temperatura, entre outros) (Joaquim et al., 1994).

Hermann \& Yang (1987) observaram diferenças na produção da cultivar PR61632 de cana-de-açúcar sobre diferentes condições de umidade dos solos, sendo que as produções nas condições de baixa umidade foram bastante inferiores às produções com condições de alta umidade.

Joaquim et al. (1994) mostraram que é possível estabelecer uma classificação preliminar do potencial de produtividade dos solos, separando os mesmos de acordo com o nível de produção.

Bittencourt et al. (1990) verificaram que a redução de produção de massa verde em cana-planta pode ser devida à fertilidade do solo. Um Latossolo Vermelho Amarelo, considerado mais fértil pelos autores, proporcionou um crescimento (produção de massa verde) maior na taxa de 30\% no período mais favorável ao desenvolvimento vegetal 
(umidade e temperatura adequados) e nos meses menos favoráveis (inverno) uma taxa 43\% maior, em relação a um solo Areia Quartzosa (menos fértil). Isso evidencia que um solo mais fértil apresenta um potencial superior de produzir massa verde e que dependendo da época (clima) existe um comportamento diferente em função do tipo de solo (ambiente).

Dias (1997) encontrou grande influência do solo na produção agrícola da canade-açúcar, além de constatar a variação do comportamento das cultivares em ambientes distintos. Estudando 6 cultivares, o autor constatou uma amplitude de variação na produção agrícola da ordem de $51 \mathrm{Mg} \mathrm{ha}^{-1}$ no Podzólico Vermelho Amarelo eutrófico textura areia/média, enquanto que na Areia Quartzosa álico a variaçìo foi de apenas 14 $\mathrm{Mg} \mathrm{ha}{ }^{-1}$, concluindo que, as cultivares expressaram melhor o seu potencial de produtividade num ambiente mais favorável.

Em experimentos de competição entre cultivares iniciados em 1972, incluindo 16 cultivares em 4 épocas de colheita em um mesmo ano e três anos consecutivos de colheita, Bassinello et. al. (1976) observaram que para três locais do Estado de São Paulo as produções de cana-planta em $\mathrm{Mg} \mathrm{ha}^{-1}$ mantiveram-se constantes para as diferentes épocas de corte, e na localidade de Bandeirantes, no Paraná, houve um aumento gradual na produção de cana-planta nas colheitas mais tardias do ano. sendo este aumento relacionado à elevada fertilidade do solo local.

Pires (1981), aplicando estudo de estabilidade fenotípica para a produção de colmos em cultivares de cana-de-açúcar, observou que as significâncias das interações "cultivares x cortes" e "cultivares x cortes x locais", detectadas na análise conjunta dos experimentos com os dois anos de colheita, indicaram que as análises de estabilidade (comportamento semelhante em vários ambientes), para cada corte. separadamente, mostraram tendências menos estáveis das cultivares no primeiro corte (cana-planta).

Bassinello (1984) avaliou a interação genótipos x ambientes em dez cultivares de cana-de-açúcar nas regiões de Araras-SP e Bandeirantes-PR. O autor colheu os materiais em 4 diferentes épocas de corte durante a safra, considerando a produtividade de colmos por três cortes consecutivos. Avaliando a análise conjunta de experimentos para todos os ambientes. a interação épocas de colheita $\mathrm{x}$ cultivares não acusou significância 
estatística para a média dos três estágios de corte em relação à produtividade. Essa tendência ocorreu para ambos os locais, indicando que não existe alteração no comportamento das cultivares de uma época para outra. O autor definiu que a melhor época para se colher a cana-planta era em junho/julho e a cana-soca em setembro/outubro, devido aos maiores ganhos de produtividade.

\subsubsection{Potencial de produção de açúcar}

A quantidade de açúcar obtido a partir do processamento industrial da cana-deaçúcar é função direta da qualidade tecnológica e da produção agrícola obtida em uma área.

Os componentes mais importantes da qualidade tecnológica da cana-de-açúcar são: teor de fibra (conjunto de substâncias insolúveis em água presentes no caldo extraído da cana-de-açúcar; para a região Centro-sul temos como teor médio 12\%) e teor de sacarose (fração que compõem os sólidos solúveis do caldo extraído da cana-deaçúcar; possui um valor ideal mínimo de 13\% para industrialização) (Stupiello, 1987).

Os componentes da qualidade tecnológica e a produção agrícola da cana-deaçúcar são dependentes da cultivar utilizada, da idade de colleita (ou fase de desenvolvimento) e dos ratores ambientais onde a cultura está inserida (condições climáticas; propriedades físicas. químicas e microbiológicas do solo; manejo empregado; entre outros) (Humbreit. 1968; Cesar et al., 1987a; Stupiello, 1987). A porcentagem de umidade nos colmos é associada à maturação da cana-de-açúcar. Quanto maior a umidade nos colmos menor a quantidade de açúcar e sacarose recuperáveis (Humbreit, 1968).

Bassinello et al. (1976), com base nas análises tecnológicas efetuadas periodicamente e levantamentos de produção agrícola de várias safras, evidenciaram a superioridade da cultivar NA56-79 em relação à cultivar CB41-76. até então mais difundida. Observaram que em produção de açúcar por unidade de área (Mg POL ha $\left.{ }^{-1}\right)$ a cultivar NA56-79 mostrou-se superior em 75\% nos 22 locais avaliados, qualificando-a como uma cultivar imprescindível no planejamento agrícola da época. 
Machado (1987) relata que a cana-de-açúcar sob condições favoráveis ao seu desenvolvimento não promove armazenamento significativo de sacarose nos colmos e ocorre o inverso quando em condições desfavoráveis, indicando que são processos que competem pelos produtos fotossintetizados disponíveis. O acúmulo de sacarose nos tecidos do colmo ocorrem quando existem restrições ao crescimento e os fatores que regulam os sistemas de síntese, transporte e acúmulo de sacarose são mantidos em níveis normais (Alexander, 1973).

Cesar et al. (1987b) relatam que o teor de sacarose nos colmos aumenta no momento em que a cana-de-açúcar cessa seu crescimento, fenômeno este favorecido pela queda de temperatura e/ou umidade, principalmente. Alexander (1973) cita que as respostas de acúmulo de sacarose podem ser similares em solos com falta ou excesso de suprimento de água.

Hermann \& Yang (1987) verificaram, estudando a cultivar PR61632 de cana-deaçúcar, que não houve diferença significativa na produção de açúcar por unidade de área em condições de diferentes umidades no solo.

Dentro dos fatores que permitem condições ambientais favoráveis ao desenvolvimento da cana-de-açúcar está a fertilidade química do solo, ressaltando que a absorção de nutrientes varia em função da umidade do solo, disponibilidade, eficiência do sistema radicular, além de outros fatores. Vários trabalhos, estudando o efeito da adubação na qualidade tecnológica desta cultura, indicaram influência dos nutrientes no processo de maturação (Orlando Filho \& Zambello Junior. 1980: Cesar et al., 1987ab; Silva \& Casagrande, 1983). De um modo geral. foram destacados o nitrogênio, que provoca diminuição no teor da pol pelo aumento da atividade bioquímica das células meristemáticas, favorecendo o desenvolvimento vegetativo da cana-de-açúcar e conseqüente diluição da sacarose no caldo (Lucchesi, 1995); o potássio, que é responsável pela translocação da sacarose para o local de armazenamento e fundamental no processo de evapotranspiração (Lucchesi, 1995), e o fósforo. responsável pelo metabolismo energético no desenvolvimento vegetal e formação da sacarose (Silva, 1983).

Como foi salientado anteriormente, a interação da cultivar com o ambiente 
promove grande influência sobre o rendimento de açúcar por unidade de área. Este rendimento é uma medida interessante pois indica o potencial de produção e retorno econômico da cultura.

Em trabalho realizado para avaliar a melhor época de colheita (maior retorno econômico) de 10 cultivares de cana-de-açúcar, foi constatado que as cultivares colhidas na época de maior quantidade de açúcar por unidade de área $\left(\mathrm{Mg}\right.$ Pol ha $\left.{ }^{-1}\right)$, proporcionam maiores lucros para as agroindústrias açucareiras (Nunes Junior \& Schouchana, 1984).

Bassinello (1984) avaliou a interação genótipos x ambientes em dez cultivares de cana-de-açúcar nas regiões de Araras-SP e Bandeirantes-PR. O autor constatou, dependendo das cultivares, uma elevação constante no rendimento de $\mathrm{Mg} \mathrm{Pol} \mathrm{ha}^{-1}$ em cana-planta, principalmente nos períodos de colheita de julho, agosto e setembro, sendo que ocorreu uma queda do valor de $\mathrm{Mg} \mathrm{Pol} \mathrm{ha}^{-1}$ no mês final de collheita (dezembro). 


\section{MATERIAL E MÉTODOS}

\subsection{Local}

Para a execução do trabalho foram selecionados, no município de Castilho (Região Noroeste do Estado de São Paulo), dois locais com solos distintos. A distância entre os locais era pequena, aproximadamente dois mil metros. A proximidade dos locais permite a redução dos efeitos do clima sob os resultados obtidos nas avaliações dos experimentos.

O município de Castilho, de acordo com a classificação de Köppen, apresenta clima Aw, ou seja, tropical de inverno seco, com chuvas no mês mais seco inferiores a $30 \mathrm{~mm}$, temperatura do mês mais quente superior a $22^{\prime \prime} \mathrm{C}$, e do mês mais frio maior que $18^{\circ} \mathrm{C}$. Na Figura 1 são apresentadas as médias mensais de precipitação do município durante o período de duração do experimento e de alguns anos anteriores.

\subsection{Cultivares de cana-de-açúcar}

No presente estudo utilizou-se as cultivares RB855113, RB855536, RB72454. RB855453, RB835019, RB835486, RB845257, SP79-1011, SP80-1842, sendo que estes materiais genéticos foram escolhidos devido ao seu potencial produtivo em outras regiões. As cultivares RB72454 e SP79-1011 ocupam grande parte dos solos na região onde foi realizado o trabalho, sendo este o principal fator de suas inclusões neste estudo.

As cultivares tem características agronômicas próprias descritas pelos programas de melhoramento que as geraram.A seguir serão listadas algumas das características agronômicas das cultivares desse estudo: 


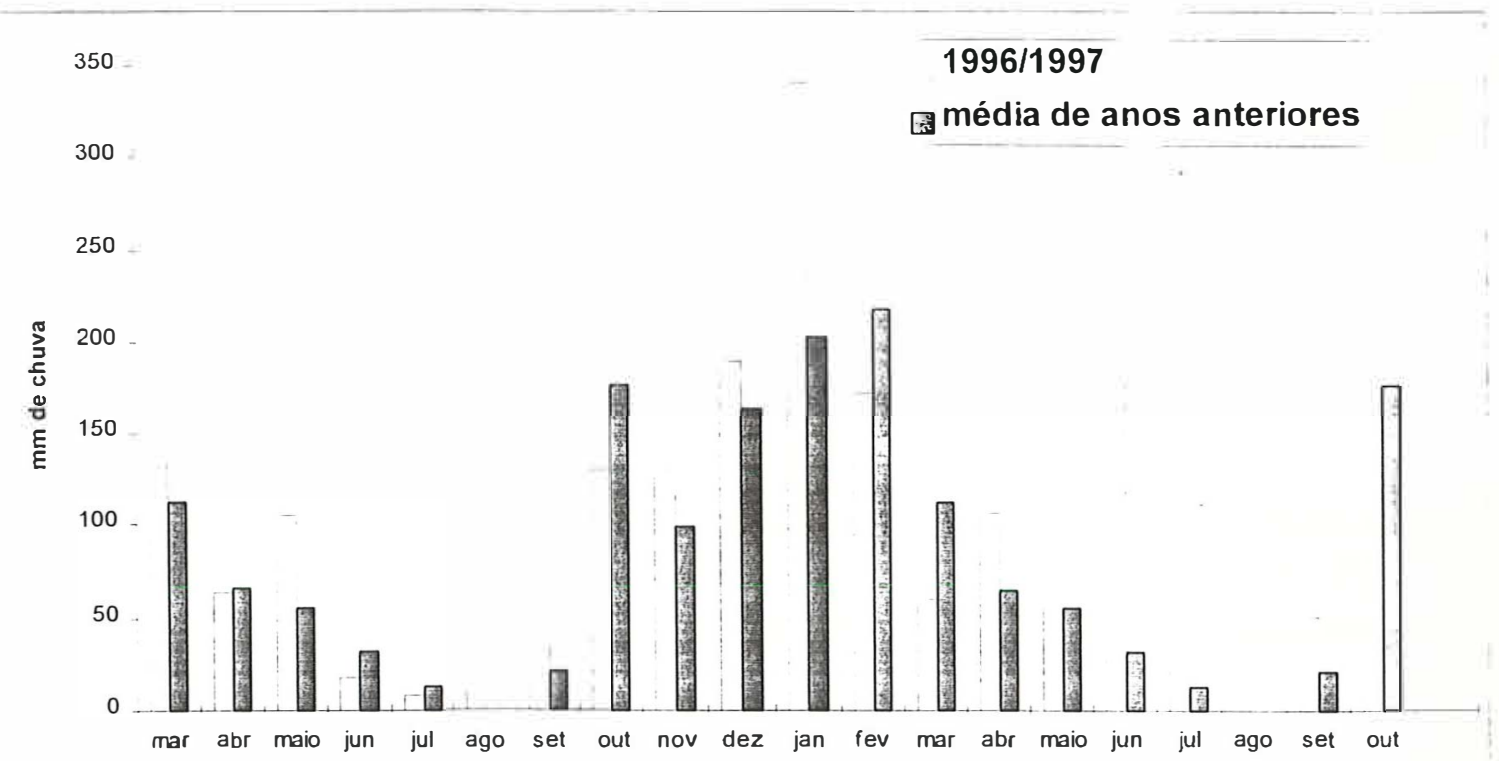

Figura 1. Precipitação mensal média de anos anteriores e do período de duração do experimento no local de estudo.

- RB855113 apresenta excelente perfilhamento e fechamento de entrelinhas; alta produção agrícola; não exigente em solos; maturação média; muito rica em sacarose; teor de fibra baixo; tombamento ausente; florescimento raro e pouco chochamento (UNIVERSIDADE FEDERAL DE SÃO CARLOS, 1999).

- RB855536 apresenta excelente perfilhamento e fechamento de entrelinhas: alta produção agrícola; não exigente em solos; maturação média; muito rica em sacarose; teor de fibra baixo; tombamento ausente; florescimento e chochamento ausentes (UNIVERSIDADE FEDERAL DE SÃO CARLOS, 1999).

- RB72454 apresenta perfilhamento médio e bom fechamento de entrelinhas; alta produção agrícola; não exigente em solos; maturação tardia; muito rica em sacarose; teor de fibra baixo; tombamento raro; pouco florescimento e chochamento (UNIVERSIDADE FEDERAL DE SÃO CARLOS, 1999).

- RB855453 apresenta bom perfilhamento e bom fechamento de entrelinhas; média produção agrícola; exigência média em solos; maturação precoce: muito rica em sacarose; teor de fibra médio; tombamento ausente; florescimento intenso e 
chochamento médio (UNIVERSIDADE FEDERAL DE SÃO CARLOS. 1999).

- RB835019 apresenta perfilhamento médio e ruim fechamento de entrelinhas: média produção agrícola; exigência alta em solos; maturação precoce; muito rica em sacarose; teor de fibra médio; tombamento raro; florescimento difícil e chochamento ausente (UNIVERSIDADE FEDERAL DE SÃO CARLOS, 1999).

- RB835486 apresenta perfilhamento médio e bom fechamento de entrelinhas; alta produção agrícola; exigência média em solos; maturação precoce; muito rica em sacarose; teor de fibra médio; bastante tombamento; florescimento médio e pouco chochamento (UNIVERSIDADE FEDERAL DE SÃO CARLOS. 1999).

- RB845257 apresenta excelente perfilhamento e bom fechamento de entrelinhas; alta produção agrícola; não exigente em solos; maturação média; muito rica em sacarose; teor de fibra médio; tombamento ausente; florescimento raro e pouco chochamento (UNIVERSIDADE FEDERAL DE SÃO CARLOS. 1999).

- SP79-1011 apresenta bom perfilhamento e bom fechamento de entrelinhas: alta produção agrícola; não exigente em solos; maturação tardia; muito rica em sacarose; teor de fibra baixo; tombamento ausente; florescimento e chochamento ausentes (Fernandes, 1991).

- SP80-1842 apresenta perfilhamento médio e bom fechamento de entrelinhas: média produção agrícola; não exigente em solos; maturação precoce; muito rica em sacarose; teor de fibra alto; tombamento comum; florescimento regular e chochamento ausente (Centro de tecnologia COPERSUCAR, 1993).

As cultivares, dos experimentos de terceira época de colheita (descritos mais a frente) foram submetidas à amostragem de folha aos nove meses após o plantio (janeiro de 1997). De cada parcela foram coletadas 10 folhas +3 , que correspondem a terceira folha com aurícula visível de cima para baixo, segundo o sistema de Kuijper (Dillewijn, 1952). Das folhas foram retiradas a parte central das lâminas (terço médio), as quais foram submetidas à análises de rotina do Departamento de Solos e Nutrição de Plantas da Escola Superior de Agricultura "Luiz de Queiroz"-ESALQ/USP para determinação da 
concentração de N, P, K. Ca, Mg e enxofre de acordo com a metodologia citada em Malavolta et al. (1997).

\subsection{Caracterização dos solos}

Foram abertas três trincheiras para melhor classificação e determinação das características físicas, físico-hídricas e químicas em cada local de estudo. Cada trincheira foi feita próxima a um dos experimentos (Figura 2).

Os solos foram analisados morfologicamente (Tabelas 1 e 2) segundo as normas da Sociedade Brasileira de Ciência do Solo (EMBRAPA. 1989), e além disso toram submetidos a amostragens deformadas e indeformadas para realização das análises físicas, físico-hídricas e químicas.

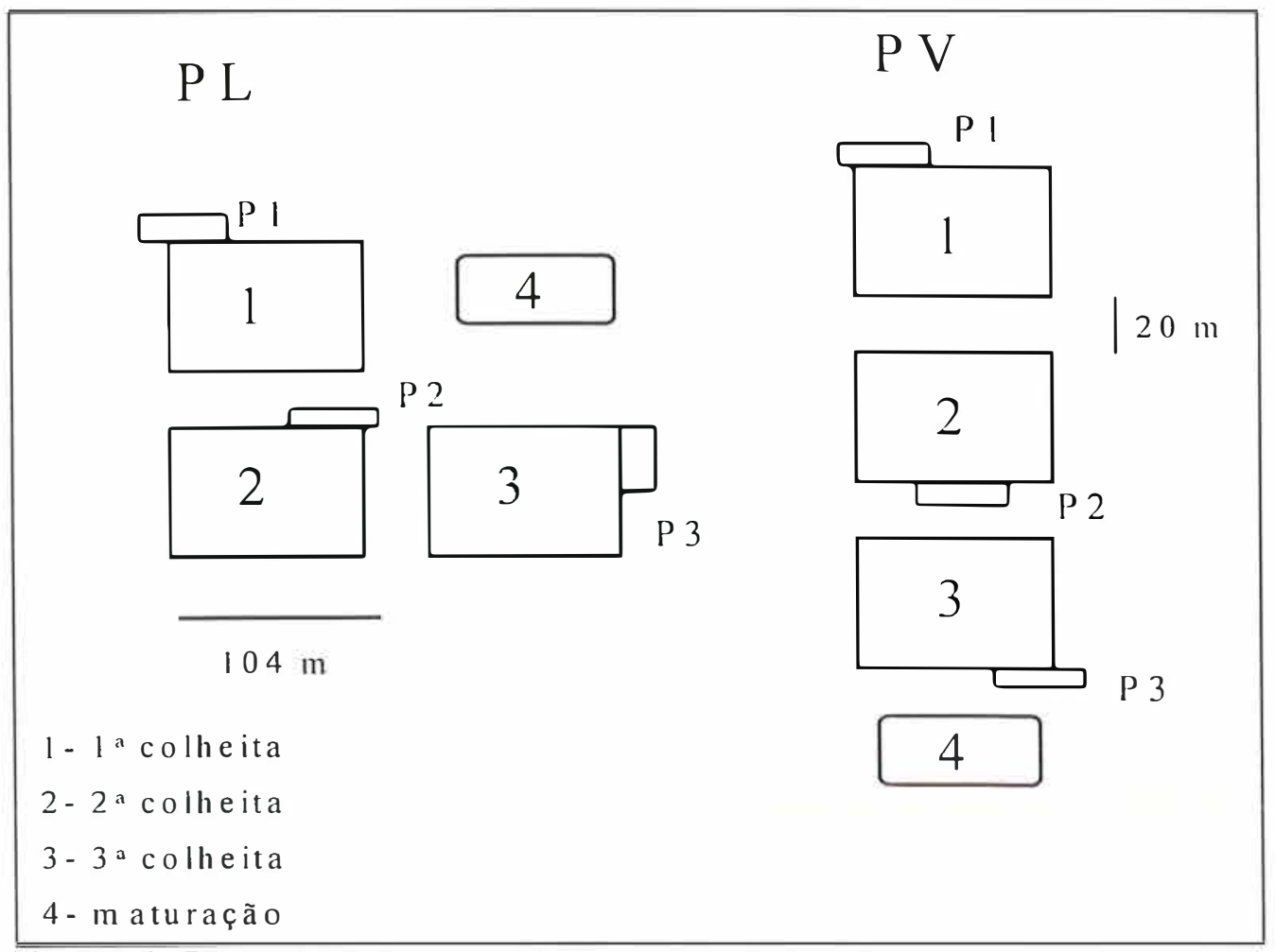

Figura 2. Disposição dos experimentos nos dois solos.

Os resultados permitiram a classificação do local 1 como Planossolo mesotrófico 
textura arenosa/média (PL) e do local 2 como Podzólico Vermelho Amarelo mesotrófico textura arenosa/média (PV), de acordo com Prado et al. (1998). Os autores sugeriram essa classificação adaptada para solos cultivados com cana-de-açúcar. na qual o termo mesotrófico é designado para solos que apresentem saturação por bases entre 30 e $50 \%$ e soma de bases maior que $12 \mathrm{mmloc} . \mathrm{dm}^{-3}$ ou saturação por bases maior que $50 \%$ e soma de bases que não atingem o mínimo para classificação como eutrófico ( 15 mmloc. $\left.\mathrm{dm}^{-3}\right)$.

As determinações físicas das amostras das trincheiras (Tabela 4 e 6), realizadas nos horizontes superficiais e subsuperficiais, foram feitas de acordo com os métodos propostos por Camargo et al. (1986) e listadas abaixo:

- granulometria, considerando quatro classes de acordo com a United States Department of Agriculture (USDA): areia grossa (AG) $(2,0$ - $0.2 \mathrm{~mm})$, areia fina (AF) $(0,2-0,05 \mathrm{~mm})$, silte $(0,05-0,002 \mathrm{~mm})$ e argila $(<0,002 \mathrm{~mm})$. A dispersão das amostras foi feita com uma mistura de hidróxido e hexametafosfato de sódio em água, e agitação por 16 horas pelo agitador rotativo de Wiegner. A separação da areia foi feita por peneira, da argila pelo método da pipeta e o silte pela diferença:

- porosidade total, macroporosidade e microporosidade;

- curvas de retenção de umidade em dois horizontes (Tabelas + e 6), segundo metodologia descrita por Richards (1954).

Para as determinações das análises químicas (Tabelas 3 e 5), as amostras foram secas ao ar, peneiradas (malha de $2 \mathrm{~mm}$ ) e homogeneizadas. Segundo a metodologia descrita por Raij \& Quaggio (1983) e Vitti (1988), foram realizadas análises de rotina e de $\mathrm{S}_{-} \mathrm{SO}_{4}$, as quais são utilizadas pelo Departamento de Solos e Nutrição de Plantas da Escola Superior de Agricultura "Luiz de Queiroz"-ESALQ/USP. Foram analisadas as seguintes características: $\mathrm{pH}$, bases trocáveis, alumínio e hidrogênio extraiveis. fósforo assimilável, carbono orgânico e $\mathrm{S}-\mathrm{SO}_{4}$. Com os resultados foram calculados os valores de CTC, soma de bases, porcentagem de saturação por bases e por aluminio. 


\subsection{Dados morfológicos}

\section{Tabela 1. Dados morfológicos dos três perfis analisados no PL.}

\section{Perfil 1}

\begin{tabular}{|c|c|}
\hline Horizontes & Descrição \\
\hline Ap & bruno amarelada escura (10YR 5/4, úmido); arenosa; subangular, média. firaca \\
\hline $0-20 \mathrm{~cm}$ & $\begin{array}{l}\text { (grãos simples); macio, muito friável, não plástico e não pegajoso; transição plana e } \\
\text { gradual. }\end{array}$ \\
\hline $\mathrm{E}$ & amarelo - brunada (10YR 6/4, úmido); arenosa; subangular, média, fíaca (grãos \\
\hline $20-50 \mathrm{~cm}$ & $\begin{array}{l}\text { simples); macio, muito friável, não plástico e não pegajoso; transição plana e } \\
\text { abrupta. }\end{array}$ \\
\hline $\mathrm{Btg} / \mathrm{E}$ & bruno amarelada (10YR 5/8, úmido); arenosa; subangular, média, moderada: macio, \\
\hline $50-75 \mathrm{~cm}$ & $\begin{array}{l}\text { friável, não plástico e não pegajoso; mosqueado pouco (l0YR } 7 / 3 \text { ); transição } \\
\text { irregular e difusa. }\end{array}$ \\
\hline $\mathrm{Btg}_{1}$ & bruno amarelada (10YR 6/6, úmido); arenosa; subangular, média, moderada: macio, \\
\hline $75-100 \mathrm{~cm}$ & $\begin{array}{l}\text { firiável, ligeiramente plástico e ligeiramente pegajoso; mosqueado abundante ( I0YR } \\
7 / 3 \text { e } 7,5 \text { YR 5/5); transição irregular e difusa. }\end{array}$ \\
\hline $\begin{array}{l}\mathrm{Btg}_{2} \\
100-120^{+} \mathrm{cm}\end{array}$ & $\begin{array}{l}\text { bruno-amarelada (10YR 6/6, úmido); arenosa; subangular. média, moderada; -, } \\
\text { friável, ligeiramente plástico e ligeiramente pegajoso; mosqueado abundante (10YR } \\
7 / 3 \text { e } 7,5 \text { YR 5/5). }\end{array}$ \\
\hline
\end{tabular}

Perfil 2

\begin{tabular}{|c|c|}
\hline Horizontes & Descrição \\
\hline Ap $0-20 \mathrm{~cm}$ & $\begin{array}{l}\text { bruno amarelada escura (10YR 5/4, úmido); arenosa; subangular, média, firaca } \\
\text { (grãos simples); macio, muito friável, não plástico e não pegajoso; transição plana e } \\
\text { gradual. }\end{array}$ \\
\hline E $20-50 \mathrm{~cm}$ & $\begin{array}{l}\text { amarelo - brunada (10YR 6/9, úmido); arenosa; subangular, média, fíaca (grãos } \\
\text { simples); macio, muito friável, não plástico e não pegajoso; transição plana e } \\
\text { gradual. }\end{array}$ \\
\hline $\mathrm{Btg}_{1} 50-85 \mathrm{~cm}$ & $\begin{array}{l}\text { bruno arilarelada (10YR 6/6, úmido); média; subangular, média, moderada; -, } \\
\text { friável, plástica e pegajosa; mosqueado pouco (10YR } 7 / 3) \text {; transição plana e } \\
\text { graduai. }\end{array}$ \\
\hline $\mathrm{Btg}_{2} 85-110^{+} \mathrm{cm}$ & $\begin{array}{l}\text { bruno amarelada (I0YR 5/3, úmido); média; subangular, média, moderada; -, } \\
\text { friável, ligeiramente plástico e ligeiramente pegajoso; mosqueado abundante (10YR } \\
7 / 3 \text { e } 7,5 \text { YR } 5 / 5 \text { ). }\end{array}$ \\
\hline
\end{tabular}

Perfil 3

\begin{tabular}{|c|c|}
\hline Horizontes & Descrição \\
\hline Ap & bruno amarelada escura (10YR 5/4, úmido); arenosa; subangular, média. fíaca \\
\hline $0-20 \mathrm{~cm}$ & $\begin{array}{l}\text { (grãos simples); macio, muito friável, não plástico e não pegajoso: transição plana e } \\
\text { gradual. }\end{array}$ \\
\hline $\mathrm{E}$ & amarelo - brunada (10YR 6/4, úmido); arenosa; subangular, média, fraca (grãos \\
\hline $20-25 \mathrm{~cm}$ & $\begin{array}{l}\text { simples); macio, muito friável, não plástico e não pegajoso; transição plana e } \\
\text { abrupta. }\end{array}$ \\
\hline Btg & amarelo - brunada (10YR 6/4, úmido); média; subangular, média, moderada; -, \\
\hline $25-$ & $\begin{array}{l}\text { friável, plástico e pegajoso; mosqueado abundante (10YR } 7 / 3) \text {; transição plana e } \\
\text { difusa. }\end{array}$ \\
\hline $\mathrm{Btg}_{2}$ & acinzentada (10YR 6/2, úmido); média: subangular, média, moderada; -, friável, \\
\hline $70-$ & osqueado abundante (10YR 7/3 e 10YR 5/3). \\
\hline
\end{tabular}


Tabela 2. Dados morfológicos dos três perfis analisados no PV.

Perfil 1

\begin{tabular}{|c|c|}
\hline Horizontes & Descrição \\
\hline $\begin{array}{l}\text { Ap } \\
0-25 \mathrm{~cm}\end{array}$ & $\begin{array}{l}\text { vermelho escuro ( } 10 \mathrm{R} 3 / 4 \text {, úmido); arenosa; subangular, média, fraca; macio, } \\
\text { muito friável, ligeiramente plástico e ligeiramente pegajoso; transição plana e } \\
\text { abrupta. }\end{array}$ \\
\hline $\begin{array}{l}\mathrm{Bt}_{1} \\
25-50 \mathrm{~cm} \\
\mathrm{Bt}_{2} \\
50-90 \mathrm{~cm} \\
\mathrm{Bt}_{3} \\
90-130^{+} \mathrm{cm} \\
\end{array}$ & $\begin{array}{l}\text { vermelho escuro ( } 10 \mathrm{R} 3 / 6 \text {, úmido); média; subangular, média, moderada: duro, } \\
\text { friável, plástico e pegajoso: cerosidade comum; transição plana e gradual. } \\
\text { vermelho escuro ( } 2,5 \mathrm{YR} 3 / 4 \text {, úmido); média; subangular, média, moderada; -, } \\
\text { friável, plástico e pegajoso: cerosidade comum; transição plana e difusa. } \\
\text { vermelho escuro ( } 2,5 \mathrm{YR} 3 / 6 \text {, úmido); média; subangular, média, moderada; -, } \\
\text { friável, plástico e pegajoso. }\end{array}$ \\
\hline \multicolumn{2}{|l|}{ Perfil 2} \\
\hline Horizontes & Descrição \\
\hline $\begin{array}{l}\mathrm{Ap} \\
0-20 \mathrm{~cm}\end{array}$ & $\begin{array}{l}\text { vermelho escuro ( } 10 \mathrm{R} 3 / 4 \text {, úmido); arenoso; subangular, média, fraca: macio, } \\
\text { ligeiramente friável, ligeiramente plástico e ligeiramente pegajoso; transição plana } \\
\text { e abrupta. }\end{array}$ \\
\hline $\begin{array}{l}\mathrm{Bt}_{1} \\
20-50 \mathrm{~cm}\end{array}$ & $\begin{array}{l}\text { vermelho escuro ( } 10 \mathrm{R} 3 / 6 \text {, úmido); média; subangular, média, moderada: duro, } \\
\text { ligeiramente friável, plástico e pegajoso; cerosidade comum; transição plana e } \\
\text { gradual. }\end{array}$ \\
\hline $\begin{array}{l}\mathrm{Bt}_{2} \\
50-90 \mathrm{~cm} \\
\mathrm{Bt}_{3} \\
90-110^{+} \mathrm{cm}\end{array}$ & $\begin{array}{l}\text { vermelho escuro (2,5YR } 3 / 4 \text {, úmido): média; subangular, média, moderada; -, } \\
\text { friável, plástico e pegajoso; cerosidade comum; transição plana e gradual. } \\
\text { vermelho escuro ( } 2,5 \mathrm{YR} 3 / 6 \text {, úmido); média; subangular, média, moderada; -, } \\
\text { friável, plástico e pegajoso. }\end{array}$ \\
\hline \multicolumn{2}{|l|}{ Perfil 3} \\
\hline Horizontes & Descrição \\
\hline $\begin{array}{l}\mathrm{Ap} \\
0-20 \mathrm{~cm}\end{array}$ & $\begin{array}{l}\text { vermelho escuro ( } 10 \mathrm{R} 3 / 4 \text {. úmido); arenoso: subangular, média, fraca: macio, } \\
\text { friável, ligeiramente plástico e ligeiramente pegajoso: transição plana e } \\
\text { clara/abrupta }\end{array}$ \\
\hline $\begin{array}{l}\mathrm{Bt}_{1} \\
20-50 \mathrm{~cm} \\
\mathrm{Bt}_{2} \\
50-80 \mathrm{~cm} \\
\mathrm{Bt}_{3} \\
80-110^{+} \mathrm{cm}\end{array}$ & $\begin{array}{l}\text { vermelho escuro ( } 10 \mathrm{R} 3 / 6 \text {, úmido); média; subangular, média, moderada: duro, } \\
\text { friável, plástico e pegajoso: cerosidade comum; transição plana e gradual } \\
\text { vermelho escuro ( } 2,5 \mathrm{YR} 3 / 4 \text {, úmido); média; subangular, média, moderada; -, } \\
\text { friável, plástico e pegajoso; cerosidade comum: transição plana e gradual } \\
\text { vermelho escuro ( } 2,5 \mathrm{YR} 3 / 6 \text {, úmido); média; subangular, média, moderada; -, } \\
\text { friável, plástico e pegajoso. }\end{array}$ \\
\hline
\end{tabular}




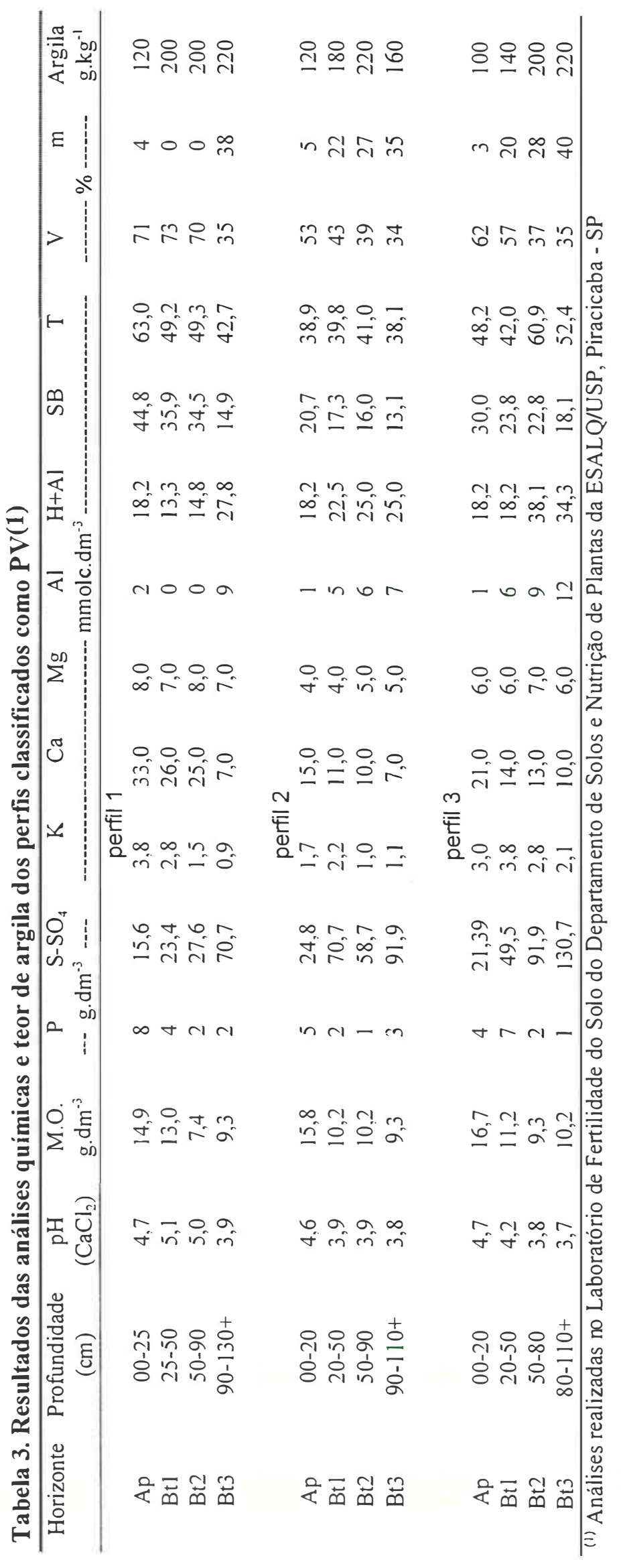




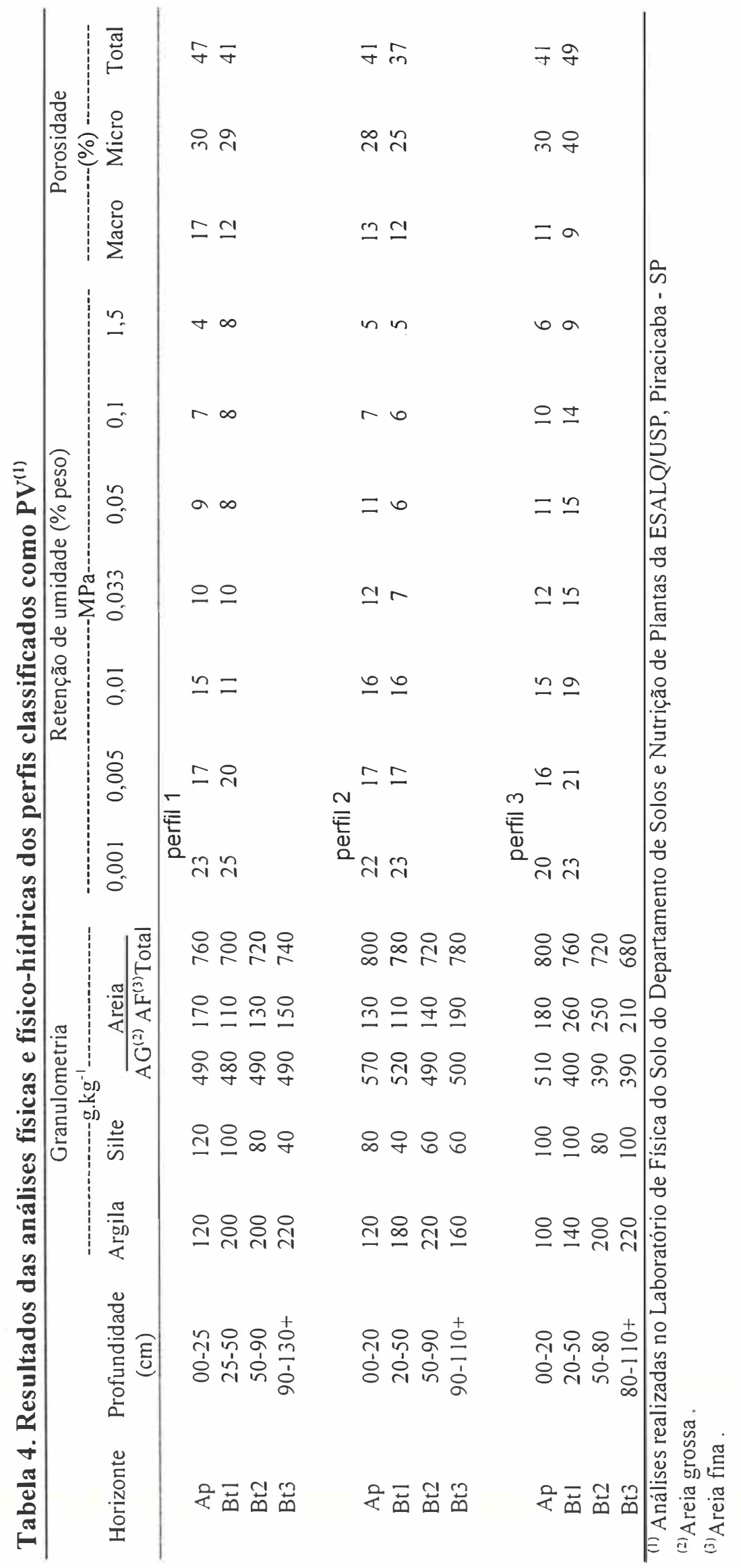




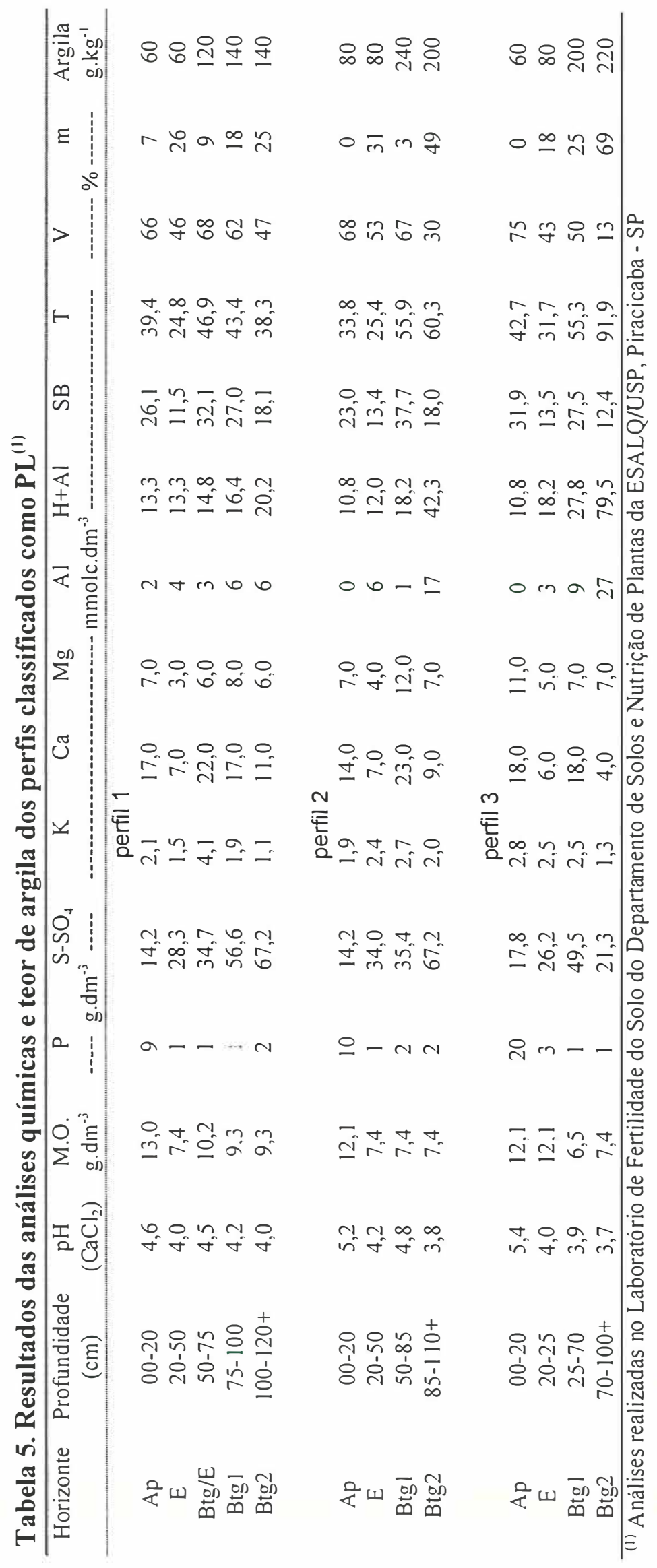




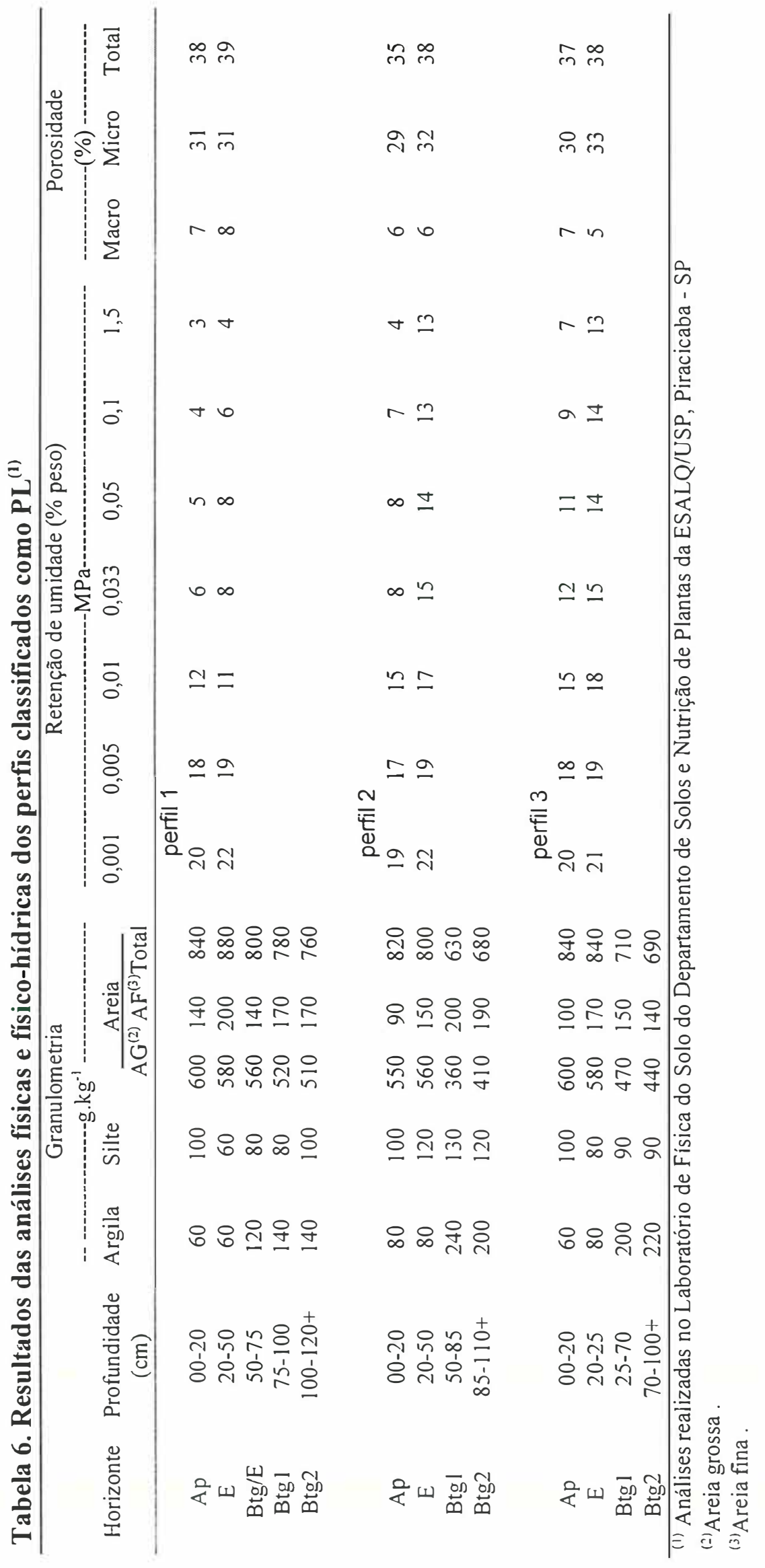




\subsection{Curvas de maturação}

Para permitir o acompanhamento da evolução das características qualitativas da cana-de-açúcar foi instalado, em cada local, um experimento que continha 7 parcelas, onde cada parcela representava uma amostragem mensal para as cultivares. Cada parcela continha as nove cultivares plantadas em 3 linhas de $3 \mathrm{~m}$. separadas entre si por $2 \mathrm{~m}$. As parcelas eram separadas entre si por 2 linhas de bordadura. Foram colhidos 10 colmos seguidos por amostra de cada linha, sendo um total de 3 amostras por cultivar por local e mês de coleta. Os experimentos de maturação foram colhidos durante o período de maio a novembro. As amostras foram identificadas e enviadas ao laboratório, onde foram desintegradas, homogeneizadas e submetidas a análises tecnológicas pelo método da prensa hidráulica (Tanimoto, 1964).

Foram analisadas as seguintes das características qualitativas da cana-de-açúcar:

- Pol \% cana (pol), que corresponde à porcentagem de sacarose aparente contida na cana-de-açúcar (Tanimoto, 1964). Com os valores da pol determina-se o período útil de industrialização que corresponde ao período no qual a cultivar apresenta mais que o valor mínimo de pol para industrialização.

- Fibra \% na cana-de-açúcar, que corresponde à porcentagem em peso da parte da canade-açúcar não solúvel em água fria (Tanimoto, 1964).

- Umidade \% dos colmos, que corresponde à porcentagem da parte do peso da cana-deaçúcar em água.

Com os dados obtidos foram confeccionadas, para cada cultivar no seu específico ambiente. curvas (gráficos: dados em função do mês de coleta) a fìm de avaliar o comportamento das cultivares em relação aos parâmetros avaliados durante o período de safra. Para isso utilizou-se a média das três amostras.

\subsection{Delineamento do experimento de produção agrícola}

Dentro de cada um dos locais estudados foram instalados três experimentos, em abril de 1996, contendo 10 cultivares com 4 repetições, no delineamento em blocos ao 
acaso, totalizando 120 parcelas. Um experimento de cada local foi collhido numa mesma época, totalizando 3 épocas de corte. A primeira colheita foi realizada nos dias 29 e 30/05/1997, marcando o início de safra da região; a segunda foi feita nos dias 14 e 15/08/97, para caracterizar o meio da safra, e a última colheita foi feita em 9 e 10/10/1997, representando o final da safra. A parcela experimental foi constituída de 5 linhas de 10 metros de comprimento, espaçadas de $1,30 \mathrm{~m}$, perfazendo uma área útil de $65 \mathrm{~m}^{2}$, para avaliação da produção agrícola (colmo, $\mathrm{Mg} \mathrm{ha}^{-1}$ ) da cana-planta. Ao redor de todos os experimentos existia uma bordadura de 2 linhas laterais, além de $3 \mathrm{~m}$ de linha plantada na cabeceira com a finalidade de eliminar as interferências climáticas nas parcelas localizadas nas extremidades. A cana-de-açúcar foi queimada, cortada. despontada e amontoada dentro de cada parcela para a pesagem dos colmos, que foi realizada com um dinamômetro preso a uma carregadeira. Com os dados obtidos foram feitos os cálculos e os pesos obtidos em $\mathrm{kg}$ por parcela foram convertidos em $\mathrm{Mg} \mathrm{ha}^{-1}$.

Utilizando uma composição dos valores da produção agrícola obtida e da pol \% cana obtém-se um parâmetro denominado $\mathrm{Mg}$ POL ha ${ }^{-1}$ (megagrama de pol produzida por hectare), que representa o rendimento de sacarose, ou a produção de açúcar por unidade de área, para cada cultivar, sendo utilizada como medida de potencial para produção de açúcar e álcool neste estudo. Para gerar este valor foi multiplicado o valor da produção agrícola pelo respectivo valor da pol \% cana do mesmo mês de colheita.

A análise de variância foi feita baseada no modelo de análise conjunta de experimentos no tempo e no espaço de McIntosh (1983). Também foi aplicado o teste de Tukey com nível de significância de $5 \%$ para as comparações das médias da produção agrícola e Mg POL ha-1. 


\section{RESULTADOS E DISCUSSÃO}

Após realizada a análise conjunta dos experimentos de produção agrícola e $\mathrm{Mg}$

POL ha ${ }^{-1}$, os resultados de análise de variância estão dispostos de forma resumida na Tabela 7.

Tabela 7. Resultado da análise de variância para produção agrícola Mg de colmos $h^{-1}$ e Mg POL ha ${ }^{-1}$.

\begin{tabular}{lccc}
\hline \multicolumn{1}{c}{ Causas da Variação } & G.L. & \multicolumn{2}{c}{ Valor de F } \\
\cline { 2 - 4 } & & Produção Agrícola & Mg POL ha $^{-1}$ \\
\hline Bloco (Solo * Epoca ) & - & - & - \\
Solo & 1 & $150,71^{* *}$ & $49,70^{* *}$ \\
Época & 2 & $5,05^{*}$ & $16,55^{* *}$ \\
Cultivares & 8 & $56,14^{* *}$ & $54,78^{* *}$ \\
Solo * Época & 2 & $15,88^{* *}$ & $7,48^{* *}$ \\
Solo * Cultivares & 8 & $2,79^{* *}$ & $4,34^{* *}$ \\
Época * Cultivares & 16 & $2,81^{* *}$ & $4,51^{* *}$ \\
Solo * Época * Cultivares & 166 & $2,14^{* *}$ & $1,78^{*}$ \\
Resíduo & 144 & - & - \\
\hline Total & 215 & - & - \\
C.V. (\%) & & 10,19 & 10,30 \\
\hline
\end{tabular}

* Significância a 5\% de probabilidade.

** Significância a $1 \%$ de probabilidade.

A análise de variância da produção agrícola $\left(\mathrm{Mg}\right.$ colmo ha $\left.^{-1}\right)$ em função do solo e da época de colheita indicou significância a $1 \%$ de probabilidade para cultivares, solo e 
as interações época*solo, época*cultivares, solo*cultivares e época*solo*cultivares (Tabela 7). Para época, a significância foi de 5\%. A análise de variância do parâmetro Mg POL ha ${ }^{-1}$ em função do solo e da época de colheita indicou significância a 1\% para época, cultivares, solo e as interações solo*época, época*cultivares, solo*cultivares. A interação tripla (época*solo*cultivares) indicou significância a 5\% de probabilidade.

\subsection{Solo}

A produção média da cana-planta $\left(\mathrm{Mg} \mathrm{ha}{ }^{-1}\right)$ no $\mathrm{PV}$ foi superior, com um rendimento agrícola médio $28 \%$ maior que a produção obtida no PL (Figura 3). A diferença na produção agrícola média ressaltou que existe uma variação no potencial de produção de colmos de cana-de-açúcar entre os solos. Dias (1997) constatou resultados semelhantes, na mesma região Noroeste do Estado de São Paulo. Estudando a produção agrícola média de seis cultivares de cana-de-açúcar, no estágio de cana-planta, em seis tipos de solos, o citado autor verificou que o solo com maior potencial de produção agrícola foi um Podzólico Vermelho Amarelo eutrófico textura arenosa/média. Dias (1997) atribuiu a vantagem produtiva desse solo em relação aos demais à associação das características físicas, que permitiram um bom armazenamento de água, e às boas condições químicas.

O PV do estudo apresenta boas características físicas e químicas, conforme consta nas Tabelas 2, 3 e 4 . A diferenciação entre a estrutura e textura do horizonte A (arenosa) e do horizonte B (média) confere a este solo uma boa capacidade de reter umidade por períodos mais prolongados. Os resultados apresentados na Tabela 4 indicam diminuição da macroporosidade na camada subsuperficial (perfil 1) e aumento da microporosidade da camada subsuperficial em relação à camada superficial (perfil 3). Os valores diferentes de macro e microporosidade entre as camadas indicam um estrangulamento na porosidade dentro do perfil do solo, o que ocasiona alterações na movimentação ascendente e descendente da água por capilaridade dentro do solo (Reichardt, 1996). Isto provoca menor perda de água por evaporação e consequentemente maior retenção de umidade na camada subsuperficial, garantindo a 
este perfil um regime de umidade údico (solos que apresentam deficiência hídrica em um período inferior a 90 dias). O fato de existir boa disponibilidade de água permite um bom aproveitamento dos nutrientes existentes no perfil do solo.

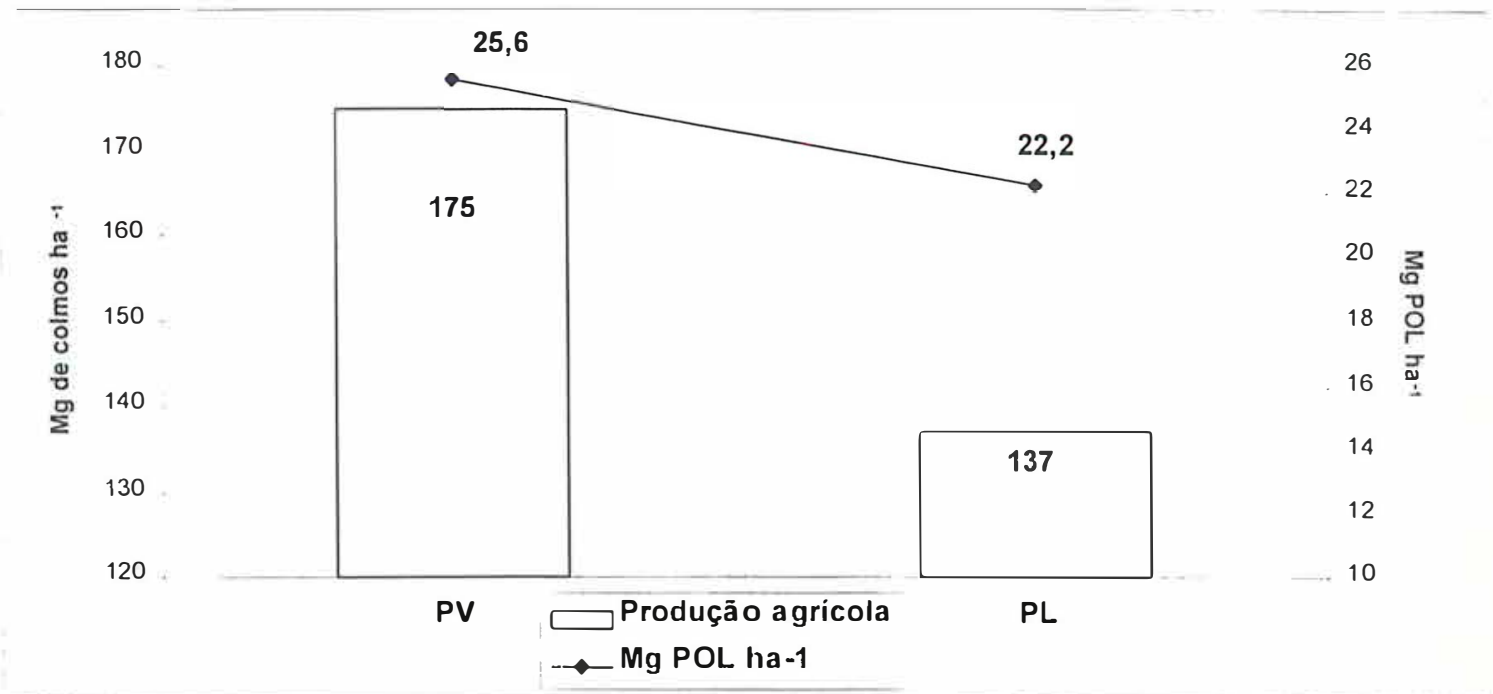

Figura 3. Produção agrícola média e Mg POL ha ${ }^{-1}$ médio nos solos.

Os valores obtidos nas análises químicas (Tabela 3) mostram elevadas concentraçòes de nutrientes dentro dos perfis do solo, destacando-se o teor de cálcio (Ca) e potássio $(\mathrm{K})$ que garantiram uma elevada soma de bases, principalmente nas duas primeiras camadas.

Provavelmente a combinação favorável entre as condições químicas e físicas deve ter favorecido um bom desenvolvimento horizontal e vertical do sistema radicular. Segundo Fauconnier \& Bassereau (1975) há concentração de $90 \%$ das raizes da cana-deaçúcar nos primeiros $60 \mathrm{~cm}$ do solo. Porém, a cana-de-açúcar possui um sistema radicular que pode atingir profundidades maiores, dependendo da cultivar, das condições químicas e de umidade do perfil de solo (Dillewijn, 1952).

Alguns trabalhos destacam a importância das características químicas nos horizontes subsuperficiais para a cana-de-açúcar. Ribeiro et al. (1984) selecionaram, através de regressões, a soma de bases do horizonte B como responsável por $27 \%$ dos $71 \%$ da variabilidade na produção da cana-de-açúcar. ou seja, esse parâmetro influencia bastante na variação da produtividade da cana-de-açúcar. Dias (1997) encontrou grande 
influência do teor de $\mathrm{Ca}$ do horizonte $\mathrm{B}$ na produção de colmos da cana-de-açúcar. atribuindo a influência desse nutriente no auxílio para um melhor desenvolvimento radicular subsuperficial e conseqüente exploração de maior volume de solo.

Os resultados das análises químicas (Tabela 3) revelaram índices ligeiramente baixos de $\mathrm{pH}$, porém os teores elevados de $\mathrm{Ca}$ em subsuperfície permitem um bom desenvolvimento do sistema radicular das plantas (Ritchey et al., 1981).

Como resultado da associação das condições químicas às condições físicas do $\mathrm{PV}$, podemos considerar que a cana-de-açúcar apresentou um desenvolvimento radicular que possibilitou melhor aproveitamento na absorção de nutrientes e água, e estes fatos contribuíram para uma produção vegetal elevada.

Os planossolos podem ser identificados como verdadeiros solos hidromórficos. submetidos a condições de excesso de água. que pode ser perene, prolongado ou temporário sazonal (Oliveira et al., 1992). Como o PL em estudo é originado de deposições aluviais ou coluviais e está localizado em uma paisagem baixa. pode apresentar uma variação de espessura nos horizontes $A+E$ dentro dos perfis (Tabela 1), que pode ocasionar problemas de excesso de água pela drenagem reduzida e altura do lençol freático. Estes fatos ficam evidentes pela grande concentração de mosqueados nos horizontes Bt dos perfis (Tabela 1 e Figura 4), que indicam ambiente de redução. ocasionado pelo excesso de água. Foi constatada uma variação da altura do lençol freático dentro da área, pois, dois dias após a abertura das trincheiras, a de número três desse solo encontrava-se parcialmente inundada (Figura 4a) o que não ocorreu nas outras trincheiras um e dois, localizadas aproximadamente a 100 e 200 metros da primeira, respectivamente (Figura 2).

Em ambientes com condições redutoras ocasionadas pela presença de água. a falta de oxigênio pode ser bastante prejudicial às plantas cultivadas que não são adaptadas, quer por influência na sua fisiologia, quer por favorecer a proliferação de doenças (Oliveira et al., 1992). Provavelmente, como principal fator limitante à produção vegetal da cana-de-açúcar nesse solo destaca-se o excesso de água em alguns períodos desse ano agrícola, que devem ter promovido condições de umidade do solo semelhantes a um regime de umidade áqüico. O regime temporário de umidade áqüico 


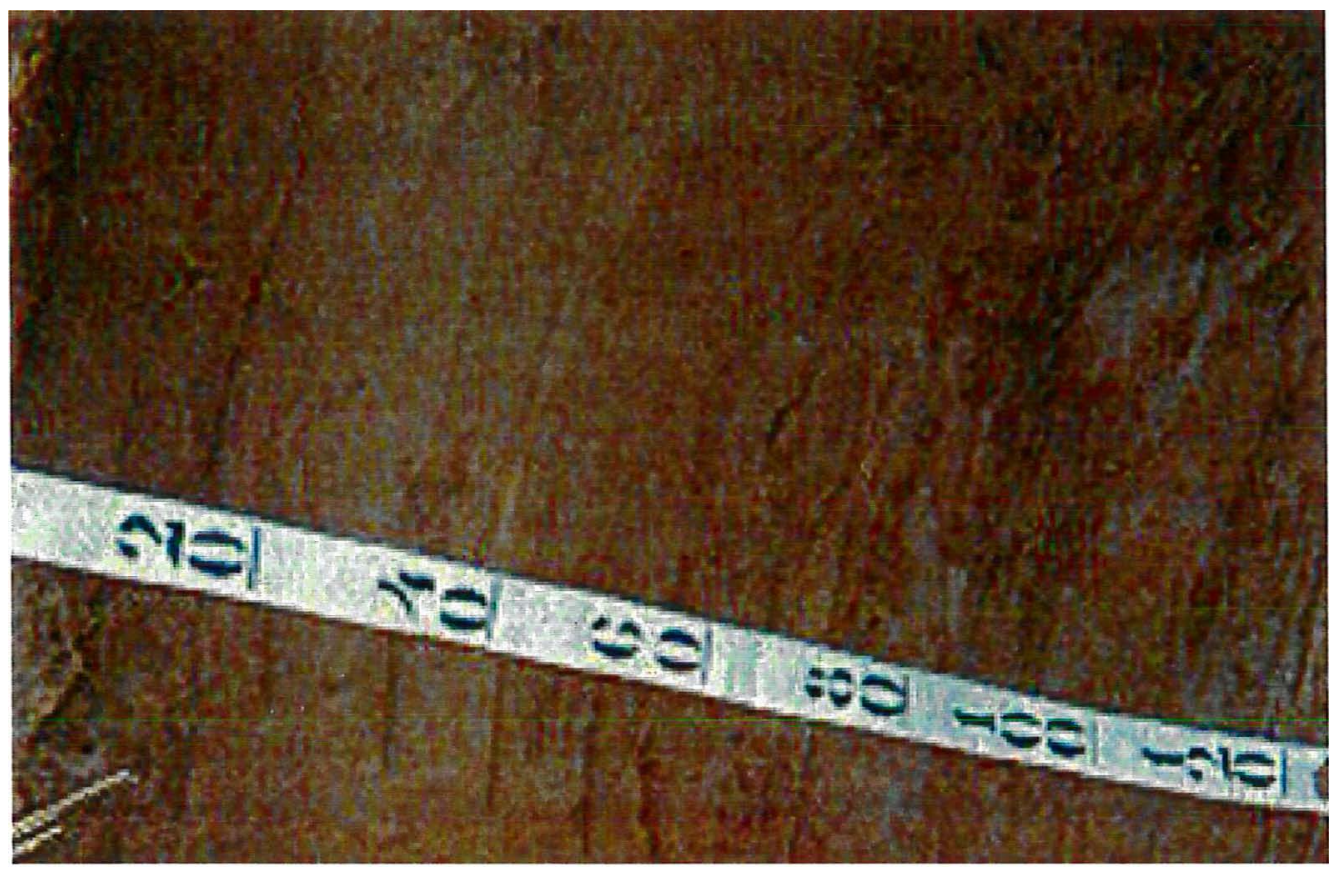

تُ

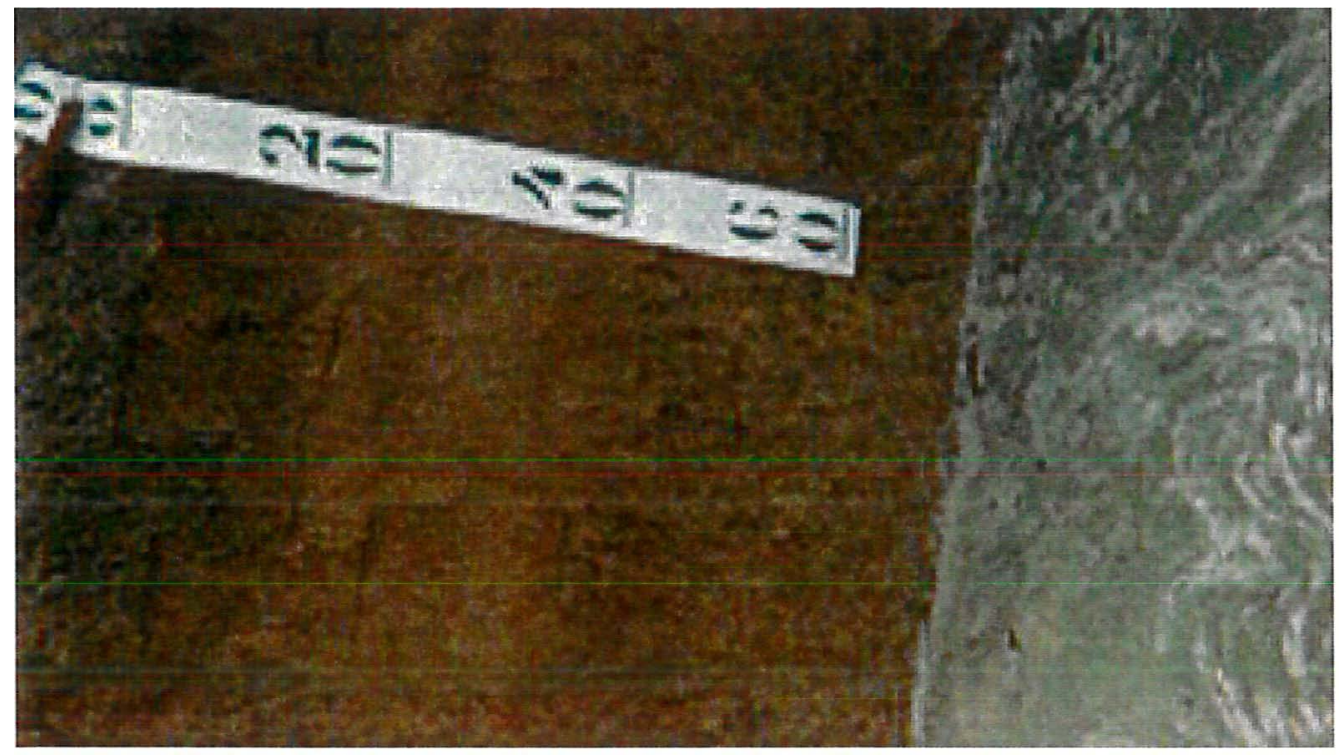

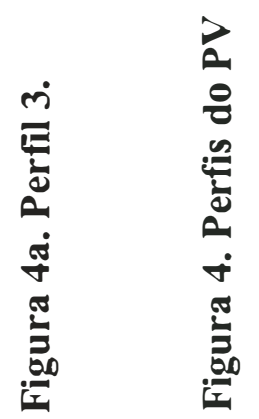


pode ter propiciado pequeno desenvolvimento radicular ou falta de aeração adequada para o funcionamento do sistema radicular da cultura. Sabe-se que em condições de umidade favoráveis a cana-de-açúcar apresenta um desenvolvimento radicular superficial (Dillewijn, 1952) e esta cultura é muito exigente em aeração, não tolerando excesso de água nos poros do solo (Lucchesi, 1995). A falta adequada de oxigênio no sistema radicular da cana-de-açúcar vai promover redução na absorção de água e nutrientes (Humbreit, 1968).

Através da Tabela 5 podemos observar as características químicas do PL. Este solo, assim como o PV, apresenta elevada saturação por bases nas primeiras camadas, sendo observado um valor elevado de saturação por alumínio no último horizonte dos perfis 2 e 3, o que não deve ser prejudicial ao desenvolvimento da cultura, pois estes valores ocorrem a mais de $70 \mathrm{~cm}$ (Tabela 5). Esta elevada saturação por alumínio no último horizonte também foi verificada no PV (Tabela 3), reforçando que este fato não deve ter influenciado produção agrícola média. Os teores dos macronutrientes K. Ca e $\mathrm{Mg}$ foram muito semelhantes dentro dos perfis dos dois solos, com exceção do baixo teor de $\mathrm{Ca}$ e $\mathrm{Mg}$ no horizonte E do PL (Tabela 3), ocasionando baixa capacidade de retenção de cátions, que é uma característica intrínseca a horizontes de máxima eluviação. As características do horizonte E não devem ter apresentado interferència na produção agrícola deste solo, pois os nutrientes $(\mathrm{N}$ e $\mathrm{P})$ que apresentaram valores de absorção diferentes entre os dois solos (Tabela 8) são nutrientes de maior concentração na camada superficial do PL (Tabela 5).

Tabela 8. Teores médios de nutrientes nas folhas das cultivares de cana-de-açúcar aos nove meses de idade.

\begin{tabular}{ccccccc}
\hline Solo & $\mathrm{N}$ & $\mathrm{P}$ & $\mathrm{K}$ & $\mathrm{Ca}$ & $\mathrm{Mg}$ & $\mathrm{S}$ \\
\cline { 2 - 8 } & & & & & & \\
\cline { 2 - 7 } & & & & & & \\
$\mathrm{PL}$ & 12,0 & 1,5 & 16,0 & 1,5 & 1,0 & 1,0 \\
$\mathrm{PV}$ & 15,0 & 2,0 & 16,0 & 1,8 & 1,2 & 1,0 \\
\hline
\end{tabular}

Nove meses após a instalação dos experimentos, o solo PV apresentou um nível 
de absorção de macronutrientes maior ou igual ao solo PL (Tabela 8). Os nutrientes que apresentaram maiores variações foram o nitrogênio. o fósforo e o cálcio. A maior absorção de nutrientes no PV deve estar associada às condições de equilíbrio dos nutrientes dentro do solo ou à eficiência do sistema de absorção das plantas nos dois ambientes, em função do excesso de água. Estes fatos permitiram maior produção agrícola média no PV.

Na média, o PV apresentou rendimento de Mg POL ha ${ }^{-1} 15 \%$ superior ao PL (Figura 3), e essa diferença se deve. principalmente. à melhor média de produção agrícola do PV. Fazendo a comparação entre a produção agrícola média e o Mg POL ha 1 médio nota-se que no PL as cultivares de cana-de-açúcar apresentaram melhores porcentagens de sacarose que no PV nas condições do ambiente agrícola de condução dos experimentos. Como a cana-de-açúcar para obter acúmulo de sacarose necessita sofrer estresse (diminuição dos fatores de produção) (Cesar et al., 1987a), sugere-se que os mesmos fatores (ocasionados pelo excesso de água) que provocaram uma menor produção agrícola no PL propiciaram também melhores taxas médias de acúmulo de sacarose (Figura 5).

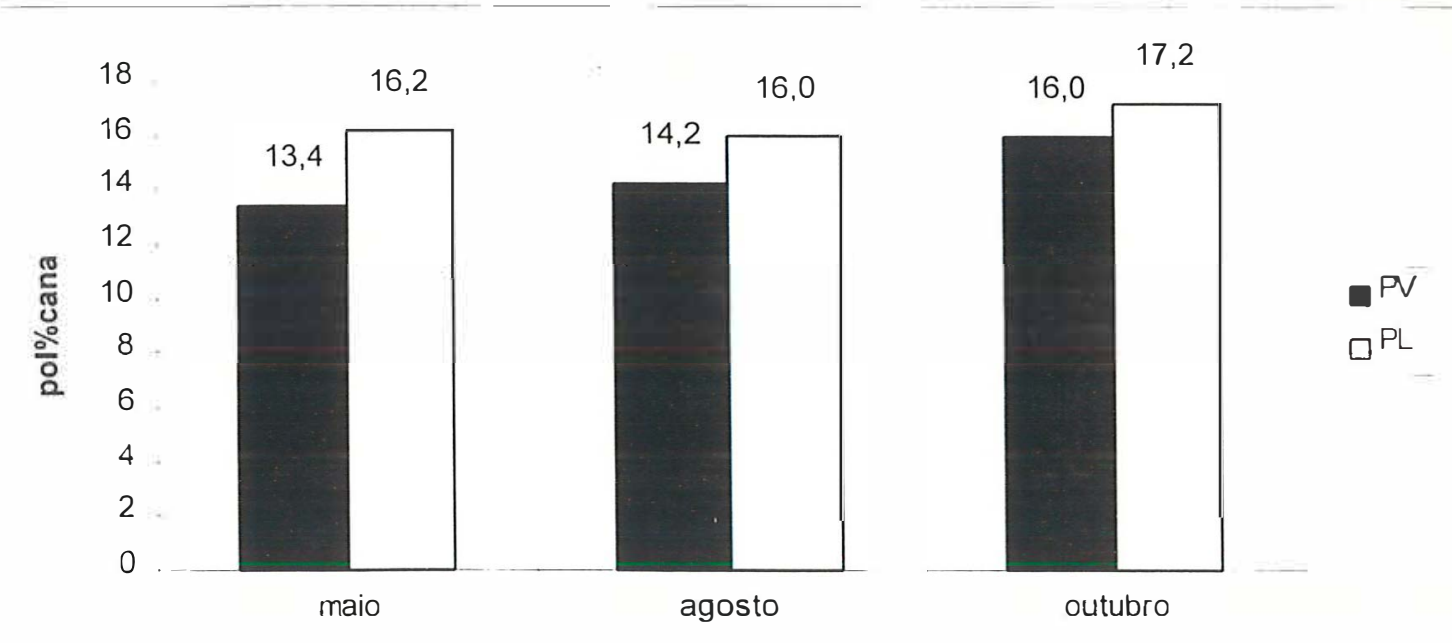

Figura 5. Pol\%cana média das cultivares em cada solo e época de colheita.

\subsection{Interação: solo $x$ cultivares}


Dentre as cultivares estudadas, as que não apresentaram diferença estatística $(P>0,05)$ na produção agrícola média das três épocas de colheita entre os solos foram RB855113, RB855453, SP79-1011, RB72454 e SP80-1842. mostrando que apresentaram maior adaptabilidade para os dois locais (Figura 6). Essas cultivares apresentaram-se menos sensíveis às diferenças dos fatores de produção que existem entre esses dois ambientes. Este comportamento ilustra bem os objetivos dos melhoristas de cana-de-açúcar, que buscam selecionar cultivares que possam produzir de forma semelhante em diferentes ambientes, ou seja, que as cultivares apresentem adaptação para vários ambientes de produção. Por outro lado. as demais cultivares mostram que nem sempre os melhoristas conseguem atingir as metas e que algumas cultivares podem expressar comportamentos variados em função de sua interação com o ambiente. dando respostas diferentes de produção agrícola.

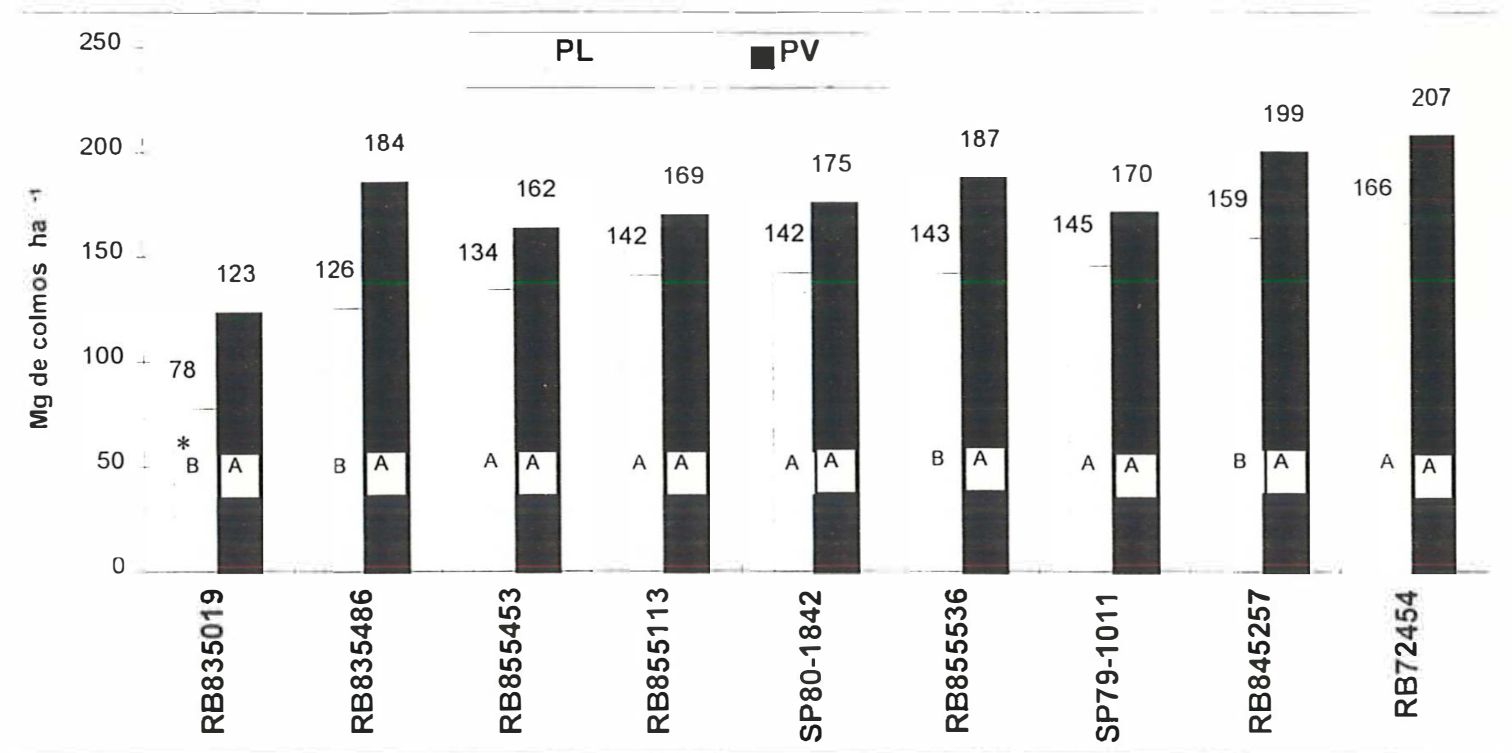

Figura 6. Produção agrícola média das cultivares em cada solo.

* Letras maiúsculas correspondem às comparações entre solos para uma mesma cultivar pelo teste de Tukey com nível de significância $(\alpha) 0,05$.

Neste mesmo contexto a cultivar SP79-1011 apresentou a sexta melhor produção agrícola no PV e a terceira melhor no PL e a cultivar RB835486 apresentou a quarta melhor produção agrícola no PV e a segunda no PL (Figura 6). destacando ainda mais 
que as cultivares podem apresentar comportamentos variados de acordo com os atributos do ambiente de produção.

Selecionando as cultivares RB855113. SP79-1011, SP80-1842, RB855536, RB855453, RB845257 e RB72454, podemos notar que a amplitude de variação de produção agrícola das cultivares foi bem diferente nos dois solos (Figura 7). No solo PL não houve diferença $(\mathrm{P}>0,05)$ de produção agrícola média entre as cultivares, enquanto que no PV ocorreu, indicando que essas cultivares podem apresentar produção agrícola diferenciada entre si, de acordo com as influências do ambiente. Essa amplitude de variação de produção agrícola das cultivares também foi constatada por Dias (1997). O autor relatou que em ambientes (solo e clima) mais favoráveis ao desenvolvimento vegetal o potencial genético de cada cultivar é mais evidenciado.

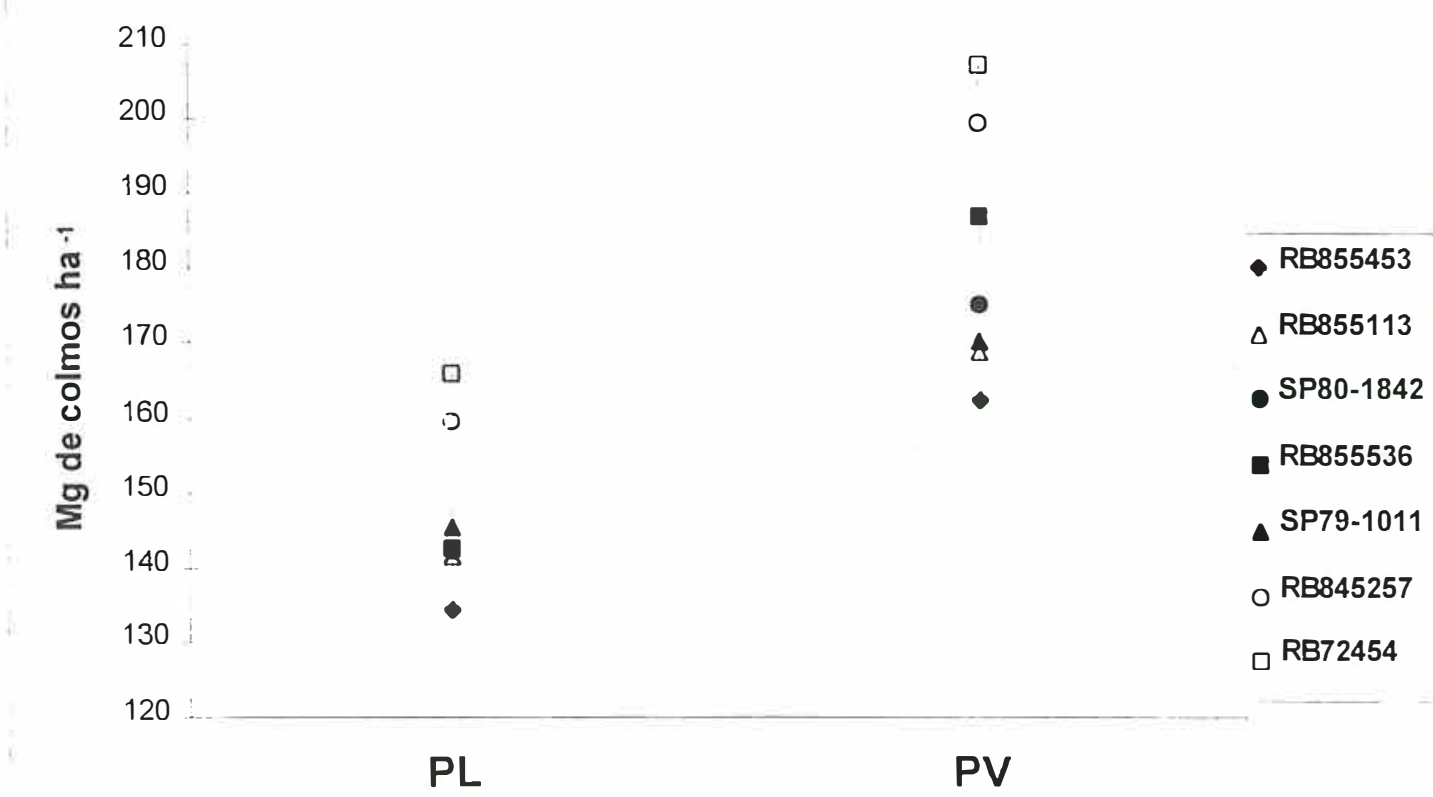

Figura 7. Amplitude de produção agrícola média em função do ambiente de desenvolvimento.

Na Figura 6 verifica-se a produção agrícola média das cultivares para ambos os solos. A cultivar de melhor desempenho foi a RB72454, que apresentou uma produção de $166 \mathrm{Mg} \mathrm{ha}^{-1}$ no PL e de $207 \mathrm{Mg} \mathrm{ha}^{-1}$ no PV, mostrando grande potencialidade de 
produção vegetal na cana-planta referente às características genéticas inerentes à planta.

O pior desempenho foi obtido pela cultivar RB835019 que apresentou diferença estatística $(P<0,05)$ na produção agrícola média das três épocas de colheita de todos as outras cultivares para ambos os solos (Figura 6), mostrando uma baixa aptidão quanto à produção vegetal para os locais onde o trabalho foi realizado, já que a sua produção de cana-planta foi muito inferior aos demais. No PV sua produção foi $23 \%$ inferior ao segundo pior desempenho, o da cultivar RB855453 com produção agrícola média de 162 $\mathrm{Mg} h \mathrm{a}^{-1}$,e no PL sua produção foi $38 \%$ inferior ao segundo pior desempenho, o da cultivar RB835486 com produção agrícola média de $126 \mathrm{Mg} \mathrm{ha}^{-1}$ (Figura 6).

Na Figura 8 podemos verificar o resultado de Mg POL ha ${ }^{-1}$ médio das cultivares para os solos estudados. As únicas cultivares que apresentaram diferença estatística significativa $(\mathrm{P}<0,05)$ entre os solos foram a RB835019 e a RB835486 ambas com maior Mg POL ha ${ }^{-1}$ no PV. As outras cultivares que apresentaram diferença estatística significativa na produção agrícola média (Figura 6) e não apresentaram Mg POL ha ${ }^{-1}$ médio diferente estatisticamente (RB855536. RB72454 e RB845257), tiveram melhor rendimento de sacarose no PL (Figura 9), minimizando a diferença de Mg POL ha" produzido entre as cultivares nos respectivos solos.

A cultivar que apresentou a menor diferença de $\mathrm{Mg}$ POL ha ${ }^{-1}$ médio entre os solos foi a RB845257, com um rendimento 5\% maior no PV (Figura 9).

Observando a Figura 8 (Mg POL ha ${ }^{-1}$ médio) e a Figura 6 (produção agrícola média), podemos notar que a RB855536 apresentou diferença de produção agrícola média 31\% superior no PV e uma diferença 25\% maior de Mg POL ha ${ }^{-1}$ médio. mostrando que a produção de sacarose média foi relativamente semelhante nos dois ambientes nas três épocas de colheita (Figura 9). Já a RB845257 apresentou uma diferença na produção agrícola média $25 \%$ maior no PV e um rendimento em Mg POL ha ${ }^{-1}$ médio apenas 5\% maior, mostrando que o PL proporcionou maior teor de sacarose médio nos colmos nas três épocas de colheita (Figura 9). Se a produção agrícola média fosse a mesma nos dois ambientes o PL apresentaria Mg POL ha ${ }^{-1}$ médio 4 e $19 \%$ maior para as cultivares RB855536 e RB845257, respectivamente. Isso mostra que as cultivares podem garantir quantidade e qualidade diferentes de matéria prima para a agroindústria em função do 
ambiente de produção.

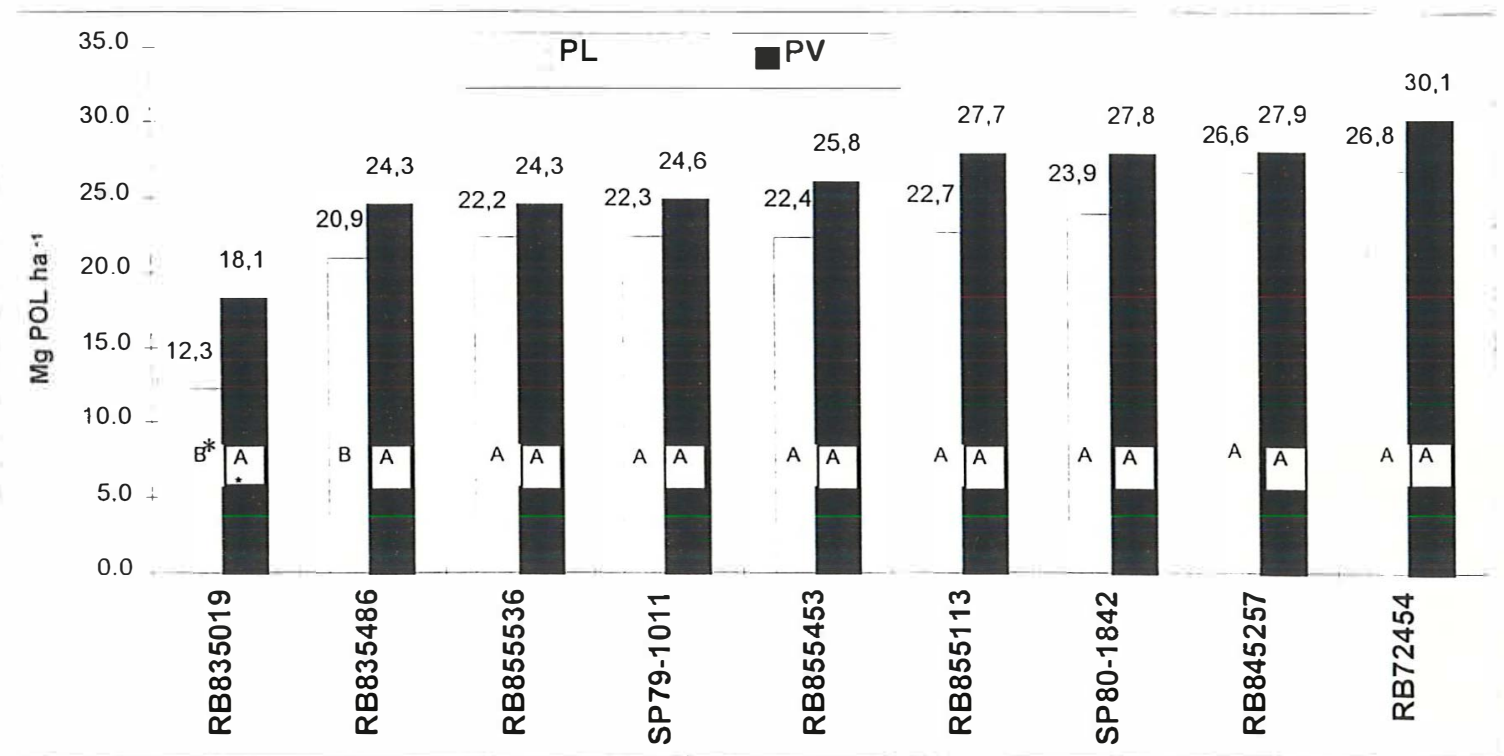

Figura 8. Rendimento de Mg POL ha ${ }^{-1}$ médio das cultivares em cada solo.

* Letras maiúsculas correspondem às comparações entre solos para uma mesma cultivar pelo teste de Tukey com nivel de significância $(\alpha) 0,05$.

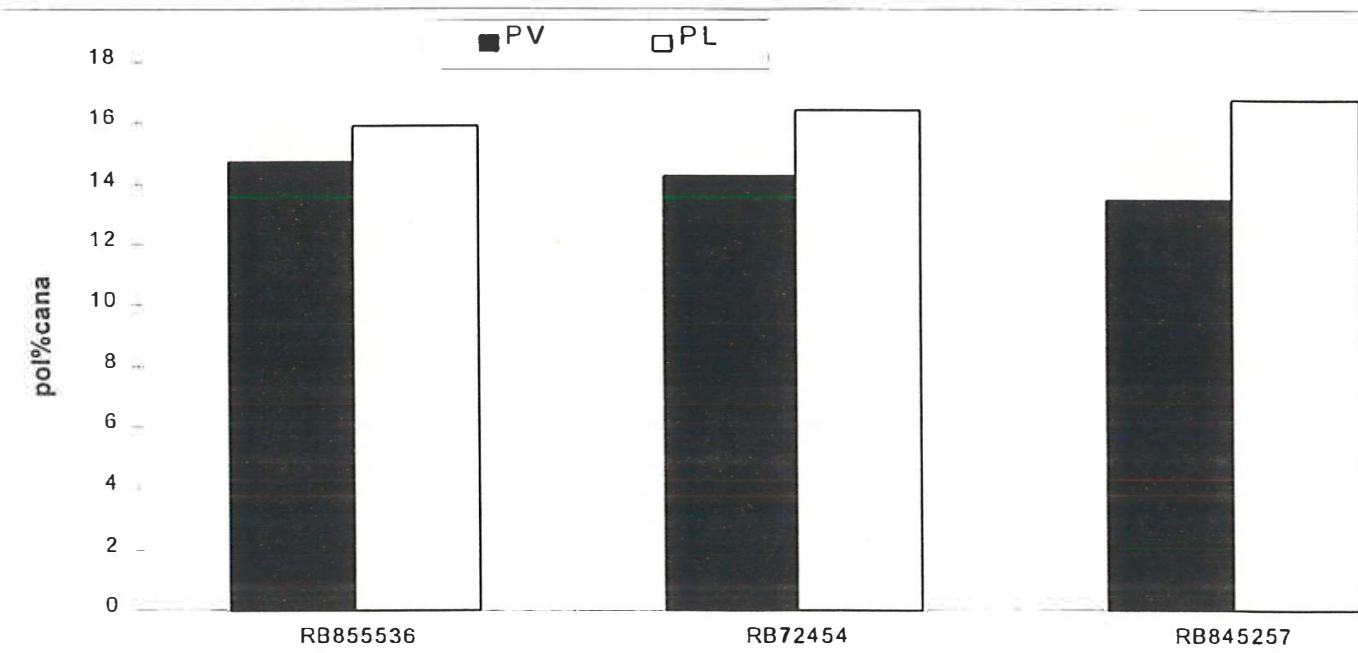

Figura 9. Pol \% cana médio das cultivares RB855536, RB72454 e RB845257 nas três épocas de colheita em cada solo.

Assim, para uma agroindústria seria vantajoso colher a cultivar RB855536 no PL, pois este apresentou a produção final média semelhante nos dois locais, e a cultivar RB845257 no PV, já que este mostrou produção final ( $\left.\mathrm{Mg} \mathrm{POL} \mathrm{ha}^{-1}\right)$ média muito 
superior neste solo.

A identificação dos fatores que influenciam diretamente no comportamento das cultivares de cana-de-açúcar são de suma importância para a locação adequada destas nos diferentes tipos de solo (ambientes de produção) dentro de sistemas eficientes de produção agrícola.

\subsection{Interação: solo x época de colheita}

Na Figura 10 estão apresentados os resultados da interação de solo e época de colheita para produção agrícola.

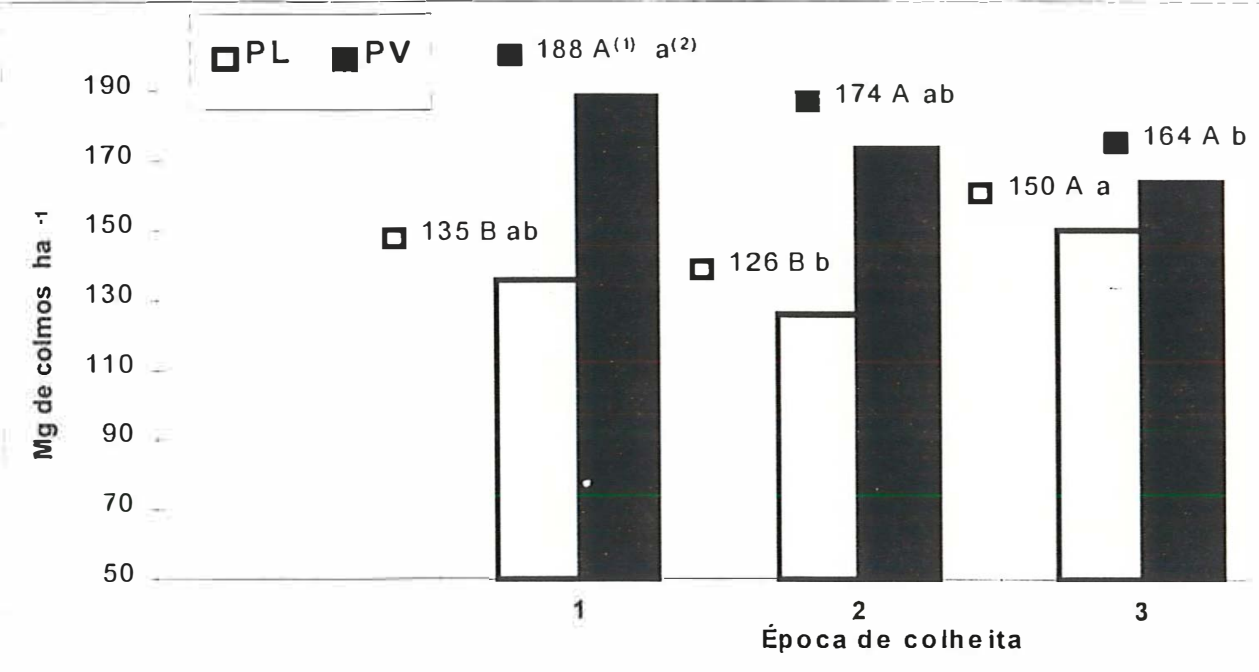

Figura 10. Produção agrícola em função da época de colheita e solo.

(1) Letras maiúsculas correspondem às comparações entre solos dentro de uma mesma época de colheita pelo teste de Tukey com nível de significância $(\alpha) 0,05$.

${ }^{(2)}$ Letras minúsculas correspondem às comparações entre épocas de colheita para um mesmo solo pelo teste de Tukey com nivel de significância $(\alpha) 0,05$.

As produções médias da cana-planta no PV apresentaram declínios da primeira época de colheita para a segunda e a terceira de $8 \%$ e de $6 \%$, respectivamente (Figura 10), mostrando que apesar do maior tempo de permanência no campo certas cultivares perderam peso. A grande produção agrícola média verificada na primeira época de colheita revela um elevado potencial desse solo para produção de cana-de-açúcar. visto 
que a primeira colheita ocorreu quando a cultura apresentava pouco mais de um ano, apesar de ser caracterizada como cana de ano e meio, em função da época de plantio.

Este desenvolvimento vegetativo elevado é o fato que levou a perda cle peso fresco das plantas nas épocas mais tardias de colheita. pois isso provocou tombamento (acamamento) de algumas cultivares. Segundo Bassinello (1976), o corte de cana-planta no final da safra pode acarretar em menores produtividades caso a cana-de-açúcar apresente perda de peso por tombamento, florescimento (juntamente à isoporização) para cultivares dotadas destas características e ampliação dos danos causados pelo ataque de pragas e doenças.

As produções agrícolas média obtidas no PL estão representadas na Figura 10. Diferentemente do PV, onde a cultura apresentou a maior produção vegetal na primeira época de colheita, no PL se obteve a maior produção agrícola na terceira época de colheita (Figura 10). A queda no volume de chuva na área durante o período anterior à terceira época de colheita (Figura 1) alterou o nível do lençol freático, modificando as condições hídricas desse solo e consequentemente todo o ambiente de desenvolvimento da cana-de-açúcar, o que acabou gerando incremento na produção agrícola média da terceira época de colheita. O abaixamento do nível do lençol freático possibilitou melhores condições de aeração do solo, permitindo maior eficiência do sistema radicular e consequentemente o in. remento na produção agrícola média. Este fato também deve estar relacionado às condições dos colmos (eretos) e ao retorno de temperaturas mais elevadas e radiação solar que favorecem o desenvolvimento vegetal da cana-de-açúcar.

Confrontando a produção agrícola média das cultivares de cana-de-açúcar entre os solos na mesma época de colheita (Figura 10). podemos verificar que a maior amplitude em $\mathrm{Mg} \mathrm{ha}^{-1}$ foi atingida na primeira época de colheita, onde a produção mostrou-se superior no PV $(\mathrm{P}<0,05)$. O mesmo ocorreu na segunda época de colheita, porém não mais na terceira época, onde os resultados foram estatisticamente iguais. A queda na amplitude está relacionada ao aumento na produção vegetal de certas cultivares no PL com o passar do tempo e declínio da produção agrícola de certas cultivares do PV devido aos fatores mencionados anteriormente.

A produção média de $\mathrm{Mg}$ POL ha ${ }^{-1}$ das cultivares no $\mathrm{PV}$ foi semelhante entre as 
épocas de colheita (Figura 11), apresentando comportamento diferente ao da produção vegetal (Figura 10). Isto mostra que os fatores que promoveram o declínio da produção vegetal promoveram melhores armazenamentos de sacarose, permitindo que na última época de colheita a cultura apresentasse a maior eficiência de produção de $\mathrm{Mg}$ POL ha-1 com a menor produção agrícola, resultando em uma matéria-prima de melhor qualidade (maior concentração de sacarose) e possivelmente menor custo de colheita e transporte (menor peso de colmos de cana-de-açúcar), dependendo do estado de acamamento.

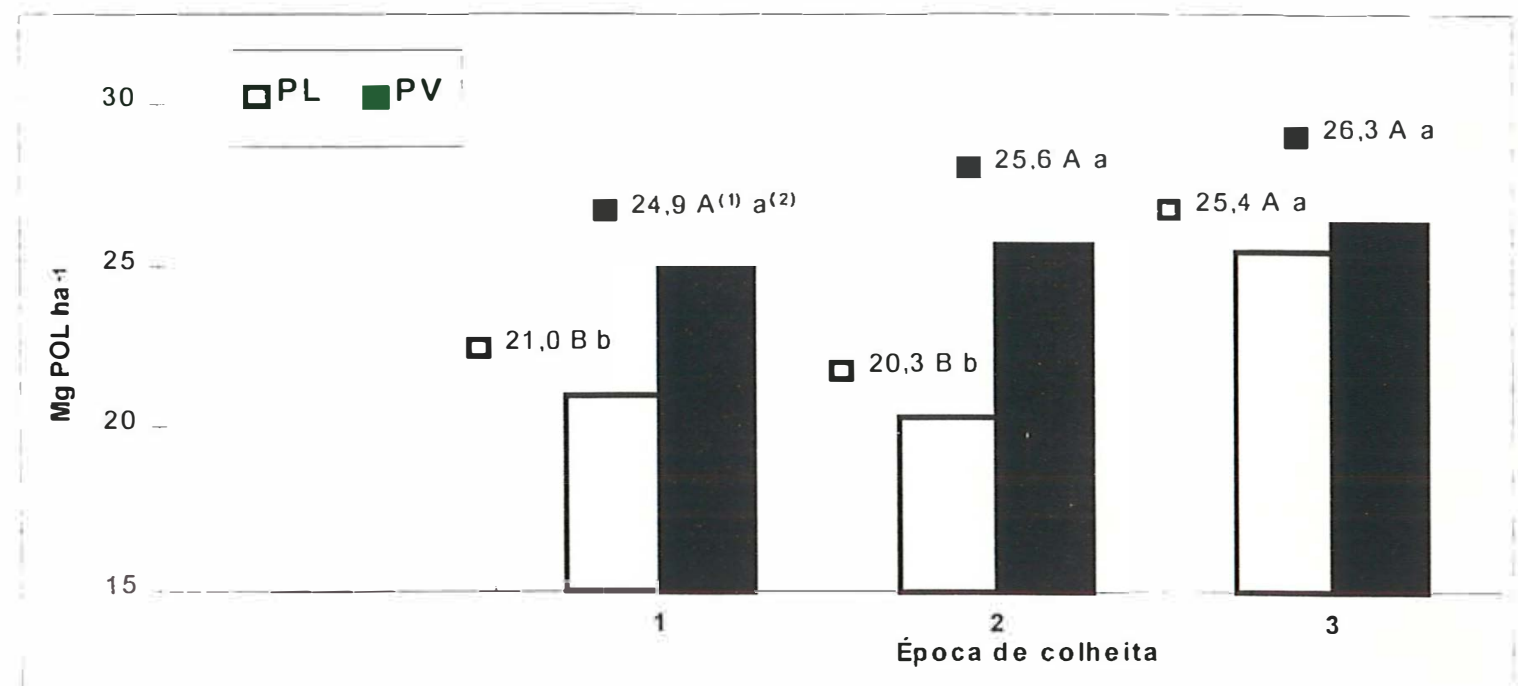

Figura 11. Rendimento de Mg POL ha ${ }^{-1}$ em função da época de colleita e solo.

(1) Letras maiúsculas correspondem às comparações entre épocas de colheita para um mesmo solo pelo teste de Tukey com nível de significância $(\alpha) 0.05$.

(2) Letras minúsculas correspondem às comparações entre solos dentro de uma mesma época de colheita pelo teste de Tukey com nível de significância $(\alpha) 0,05$.

No PL a terceira época de colheita foi que apresentou o maior rendimento médio em Mg POL ha' ${ }^{-1}$, sendo que esse valor difere estatisticamente $(\mathrm{P}<0,05)$ das duas primeiras, que não foram diferentes estatisticamente (Figura 11). Na terceira época de colheita a cultura apresentou a maior média em Mg POL ha ${ }^{-1}$, assim como no PV. porém ocorreu o inverso com a produção agrícola média, que também mostrou-se maior nessa mesma época de colheita. Assim, esse ambiente não apresentou o efeito esperado na queda da pol \% cana, devido ao incremento de produção na última época de colheita.

A primeira época de colheita apresentou $\mathrm{Mg}$ POL ha-1 médio diferente 
estatisticamente entre os solos (Figura 9), mostrando a superioridade do solo PV. Do mesmo modo foi a segunda época de colheita. Na terceira época de colheita não ocorreu mais diferença estatística significativa $(P>0,05)$, cheggando a valores muito próximos.

\subsection{Interação: época de colheita $x$ cultivares}

Na Tabela 9 podemos verificar os resultados da produção agrícola obtida da interação de cultivar e época de colheita.

Tabela 9. Produção agrícola média $\left(\mathrm{Mg} \mathrm{ha}^{-1}\right)$ em diferentes épocas de colheita para os dois solos.

\begin{tabular}{|c|c|c|c|c|c|c|}
\hline \multicolumn{7}{|c|}{ Epoca de colheita } \\
\hline & $1^{a}$ & & $2^{a}$ & & $3^{a}$ & \\
\hline$\overline{R B 835019}$ & 116 & $A^{(T)} \bar{b}^{(2)}$ & 94 & AC & 91 & $\mathrm{Ab}$ \\
\hline SP79-1011 & 149 & $A a b$ & 154 & $A a b$ & 170 & $\mathrm{~A}$ a \\
\hline RB855113 & 156 & $A a b$ & 154 & $A a b$ & 156 & $\mathrm{~A}$ a \\
\hline RB855453 & 157 & $\mathrm{~A} a b$ & 130 & $\mathrm{~A} b \mathrm{bc}$ & 158 & $\mathrm{~A} \mathrm{a}$ \\
\hline SP80-1842 & 155 & $A a b$ & 160 & $\mathrm{~A} a \mathrm{ab}$ & 161 & A a \\
\hline RB835486 & 159 & $A a b$ & 142 & A abc & 164 & A a \\
\hline RB855536 & 179 & A a & 161 & $A a b$ & 154 & A a \\
\hline RB72454 & 193 & A a & 183 & A a & 183 & A a \\
\hline RB845257 & 194 & A a & 171 & $A a b$ & 173 & A a \\
\hline
\end{tabular}

(1) Letras maiúsculas correspondem às comparações entre épocas de collheita para uma mesma cultivar pelo teste de Tukey com nivel de significância $(\alpha) 0,05$.

(2) Letras minúsculas correspondem às comparações entre cultivares dentro de uma mesma época de collheita pelo teste de Tukey com nível de significància $(\alpha) 0,05$.

As produções agrícolas média das cultivares não apresentaram diferença estatística significativa $(\mathrm{P}>0,05)$ entre as 3 épocas de colheita, o cue também foi observado por Bassinello (1984), que, estudando o comportamento de algumas cultivares de cana-de-açúcar, não constatou diferença estatística significativa de uma mesma cultivar, no estágio de cana-planta, quando colhida em quatro diferentes épocas. dentro de uma mesma safra, em dois locais com solos diferentes. 
Resultado semelhante ao da análise da produção agrícola média foi verificado na análise de $\mathrm{Mg}$ POL ha ${ }^{-1}$ nas três épocas de colheita (Tabela 10). Cabe ressaltar que certas cultivares apresentaram fortes tendências para uma melhor época de colheita para esses ambientes de estudo.

Tabela 10. Rendimento de Mg POL ha ${ }^{-1}$ médio em diferentes épocas de colheita para os dois solos.

\begin{tabular}{|c|c|c|c|c|c|c|}
\hline \multicolumn{7}{|c|}{ Época de colheita } \\
\hline & $1^{a}$ & & $2^{a}$ & & $3^{a}$ & \\
\hline RB835019 & 17,0 & $A^{(1)} b^{(2)}$ & 14,2 & $A C$ & 14,4 & $\mathrm{Ab}$ \\
\hline SP79-1011 & 20,2 & $A a b$ & 22,9 & $A a b$ & 27,3 & A a \\
\hline RB855113 & 21,7 & $A a b$ & 22,8 & A ab & 25,9 & A a \\
\hline RB855453 & 21,8 & $A a b$ & 20,5 & $A b c$ & 27,7 & A a \\
\hline SP80-1842 & 22,7 & $A a b$ & 24,8 & $A a b$ & 27,0 & A a \\
\hline RB835486 & 22,9 & $A a b$ & 22,2 & A $a b c$ & 27,9 & A a \\
\hline RB855536 & 25,9 & A a & 24,9 & $A a b$ & 24,2 & A a \\
\hline RB72454 & 27,1 & A a & 28,3 & A a & 30,0 & $\mathrm{~A} a$ \\
\hline RB845257 & 27,2 & $\mathrm{~A} a$ & 26,1 & $A a b$ & 28,5 & $\mathrm{~A} a$ \\
\hline
\end{tabular}

TI Letras maiúsculas correspondem às comparações entre épocas de colheita para uma mesma cultivar pelo teste de Tukey com nível de significância $(\alpha) 0,05$.

(2) Letras minúsculas correspondem às comparações entre cultivares dentro de uma mesma época de colheita pelo teste de Tukey com nivel de significância $(\alpha) 0,05$.

Como pode ser visto na Tabela 10, a cultivar RB835019 mostrou uma produção de $\mathrm{Mg}$ POL ha'-1 superior na primeira época de colheita, sugerindo que esta seria a melhor época para se colher esta cultivar. Além dessa, outra que mostrou melhor rendimento quando colhida na primeira época foi a RB855536. Todos as demais cultivares apresentaram a maior produção de $\mathrm{Mg}$ POL ha ${ }^{-1}$ na última época de colheita. Essa tendência sugere que dependendo da época de colheita as agroindústrias açucareiras podem obter matéria-prima de melhor qualidade programando um manejo de colheita eficiente, através da avaliação do desempenho das cultivares em função da época de colheita dentro da safra. 
Tanto na Tabela 9 como na Tabela 10 as cultivares apresentaram diferença estatística significativa entre si. Isso mostra a influência do material genético na variação da produção de $\mathrm{Mg}$ POL ha-1 em função da época de colheita das cultivares e que a seleção de cultivares para uma agroindústria açucareira pode representar uma melhor exploração agrícola, revertendo em maiores rendimentos econômicos.

\subsection{Influência do ambiente na produção agrícola da cana-de-açúcar}

Na Figura 12, podemos notar que no PV as cultivares apresentaram uma amplitude maior na produção agrícola na primeira época de colheita $(71 \mathrm{Mg}$ de colmos $\mathrm{ha}^{-1}$ ), a qual diminuiu um pouco na segunda (62 $\mathrm{Mg}$ de colmos ha ${ }^{-1}$ ) e diminuiu muito na terceira (29 $\mathrm{Mg}$ de colmos ha ${ }^{-1}$ ). No PL foi diferente, a amplitude foi de $32 \mathrm{Mg}$ de colmos ha-1 na primeira época de colheita, a qual aumentou na segunda (45 $\mathrm{Mg}$ de colmos ha ${ }^{-1}$ ) e mostrou a maior diferença na terceira época (54 $\mathrm{Mg}$ de colmos ha ${ }^{-1}$ ). Segundo Dias (1997), quando em condições de melhor ambiente de desenvolvimento, as cultivares de cana-de-açúcar podem expressar melhor o seu potencial genético de produtividade apresentando maior amplitude de variação de produção.

No PL podemos notar que ocorreu o inverso; a alteração das condições do solo promoveu uma melhora no ambiente e as cultivares puderam expressar melhor o seu potencial genético de produtividade. As cultivares podem apresentar comportamentos bastante distintos, ou seja, apresentam comportamentos diferentes com a alteração do ambiente ou possuem adaptação diferente conforme o ambiente $\mathrm{O}$ comportamento de uma cultivar foi diferente nos dois ambientes e o comportamento das cultivares foi diferente em um mesmo ambiente (Figura 12). Como exemplo podemos destacar a cultivar RB845257, a qual, no PL, teve nas duas primeiras épocas de colheita produções semelhantes e na terceira época apresentou uma produção mais elevada. Já no PV, a primeira época foi mais produtiva, ocorrendo um decréscimo acentuado na produção para as outras épocas. Além disso. a cultivar RB855536 apresentou produção descrescente no PL, sendo semelhante ao comportamento da RB845257 no PV. e a cultivar SP80-1842 teve produções semelhantes nas três épocas de colheita. no PV. 
mostrando comportamento diferente da RB845257 neste mesmo solo. Isso mostra a importância da locação das cultivares em ambiente adequado (solo e clima) para melhor aproveitamento de seu potencial genético.

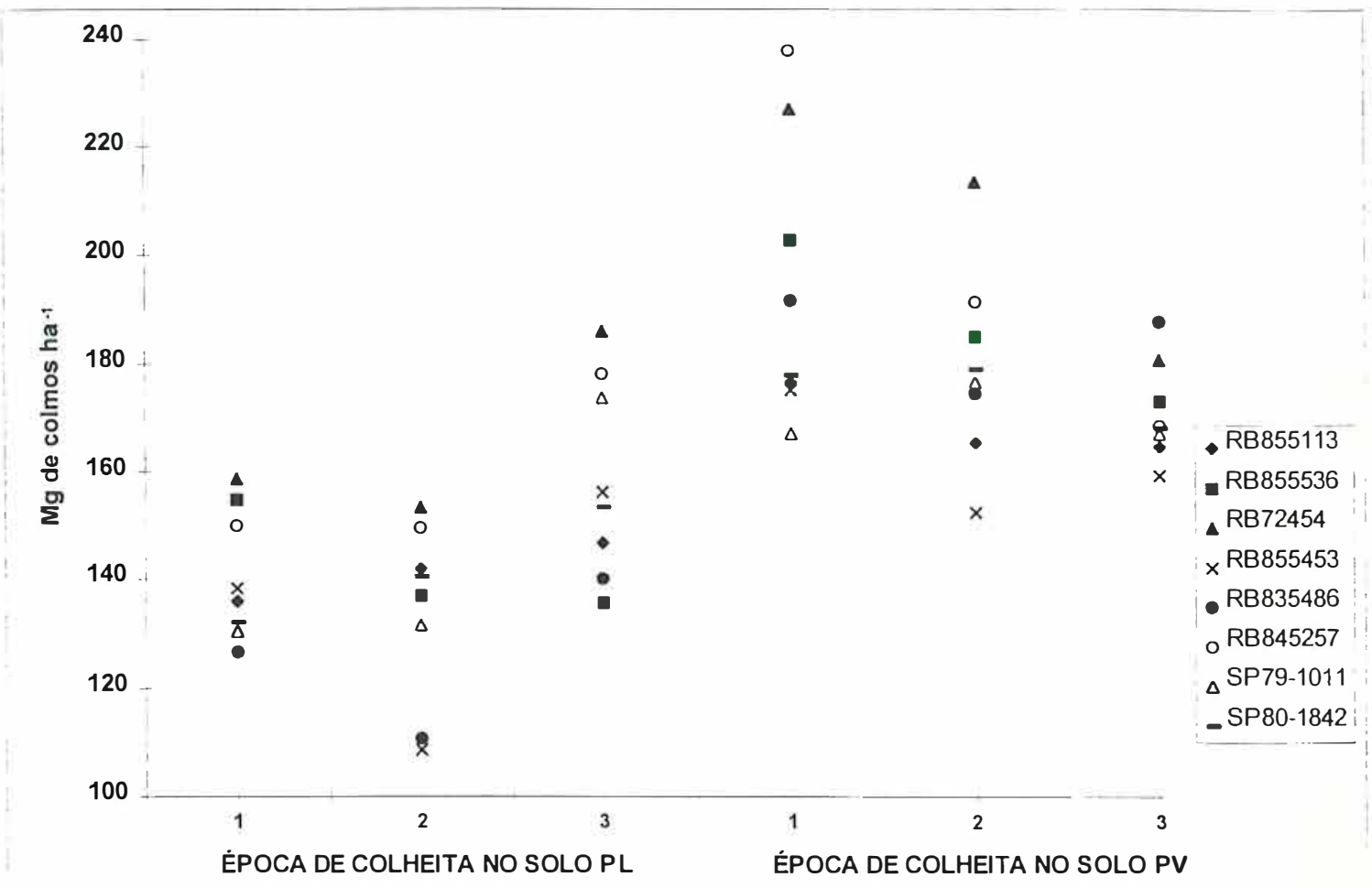

Figura 12. Produção agrícola das cultivares em função da época de colheita e tipo de solo.

\subsection{Comportamento das características tecnológicas das cultivares em função do ambiente}

Para ilustrar o comportamento diferente das características tecnológicas avaliadas nos dois ambientes em estudo, foram selecionadas curvas de amostragem mensais de algumas cultivares e as curvas de uma média geral de todas as cultivares.

A cultivar RB855113 durante as amostragens sempre apresentou os valores da pol \% cana maiores no PL, com exceção do mês de novembro (Figura 13). A maior amplitude do valor da pol \% cana entre os solos foi atingida no mês de maio, registrando uma diferença de $4,4 \%$ na pol \% cana. o que representa um potencial de produção de açúcar em torno de $40 \%$ maior. 


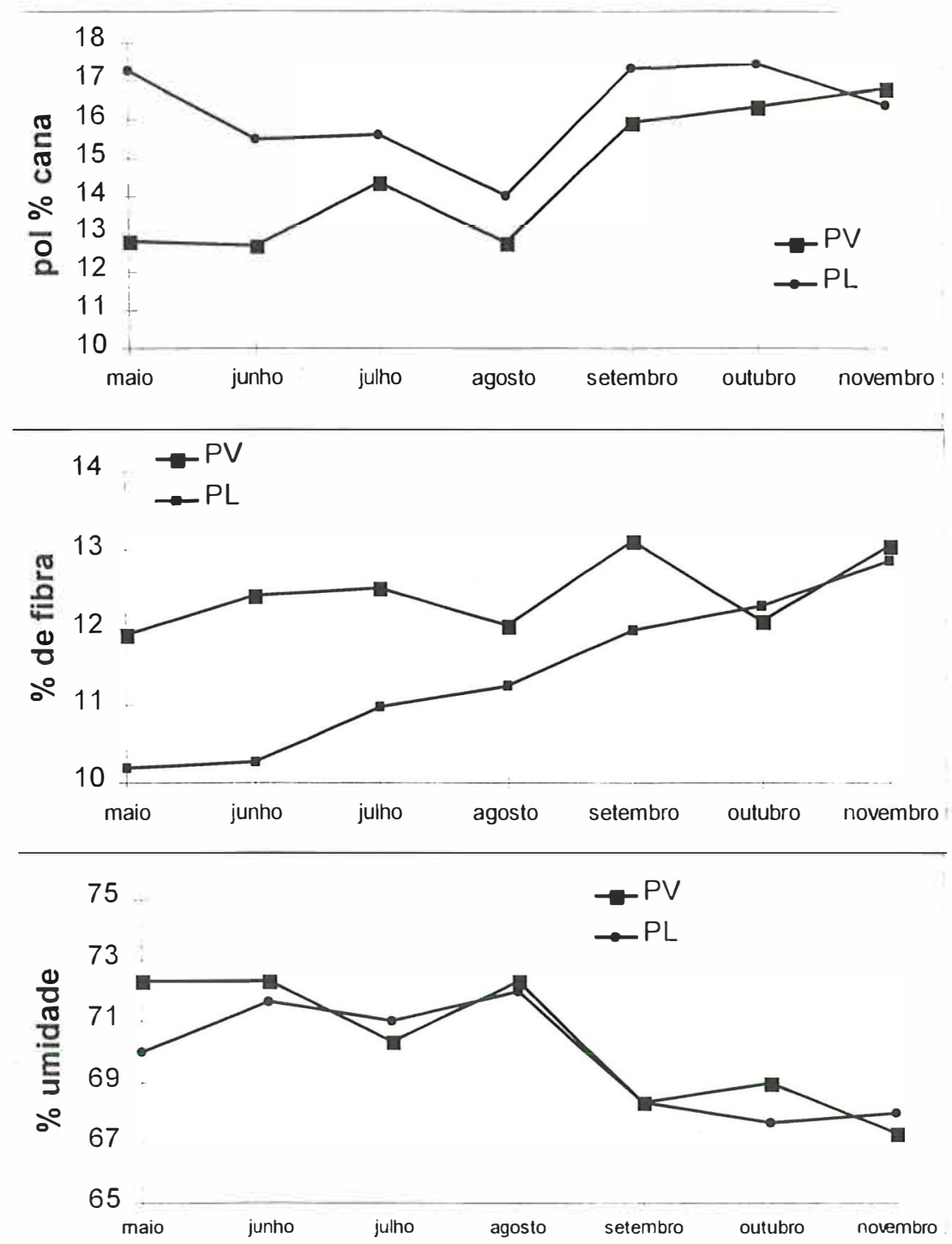

Figura 13. Características tecnológicas da cultivar RB855113

Quando a cana-de-açúcar apresentar valor de pol \% cana superior a 13 esta encontra-se apta para uma industrialização rentável (Stupiello. 1987). Em todas as amostragens realizadas no PL, esta cultivar sempre apresentou valores da pol \% cana maior que o recomendado, mostrando-se apta para ser colhida. Isto mostra uma maturação precoce e relativamente estável, acasionada pelo ambiente ( excesso de água), dessa cultivar no PL, apesar de ser enquadrada como uma cultivar de maturação média. 
Isso indica que seu cultivo neste solo pode auxiliar o manejo de colheita de uma agroindústria, devido ao longo período útil de industrialização. Já no PV, a maturação dessa cultivar foi elevando-se com o decorrer do tempo e nos primeiros meses de amostragem esta mostrou-se inapta para a colheita. O que limita muito as opções de época de colheita.

Os valores da fibra dessa cultivar foram mais elevados no PV, principalmente nos primeiros meses de amostragem. O comportamento da porcentagem de fibra dessa cultivar foi bem variado nos dois solos, enquanto que no PV ocorreu um ligeiro aumento nos três primeiros meses e depois valores intercalados de alta e baixa, no PL houve um aumento praticamente retilíneo, atingindo o maior valor no último mês (Figura 13). Os resultados mostram que no PV ela apresentou as porcentagens de fibra mais próximas ao ideal, em torno de 12,5 \% (Stupiello, 1987). Já os resultados obtidos no PL mostram uma produção muito baixa de fibras, o que pode comprometer o suprimento de bagaço como combustível dentro do processo industrial de fabricação do açúcar ou álcool.

A curva de umidade (Figura 13) apresentou valores próximos nos dois solos. sendo no mês de maio a maior diferença, onde também foi constatada a maior diferença entre os valores de pol \% cana dos dois solos. No mês de agosto verifica-se aumentos na porcentagem de umidade desta cultivar nos dois solos e um declínio da pol \% cana. porém a porcentagem de fibra só decresceu no $\mathrm{PV}$, mostrando comportamento diferente nos dois solos. Esta resposta diferente está relacionada às condições do ambiente onde a cultura está inserida.

A cultivar RB855536 sempre apresentou maiores valores da pol \% cana no PL. com exceção do mês de setembro, onde ocorreu a inversão e no PV ocorreu um valor maior (Figura 14). 


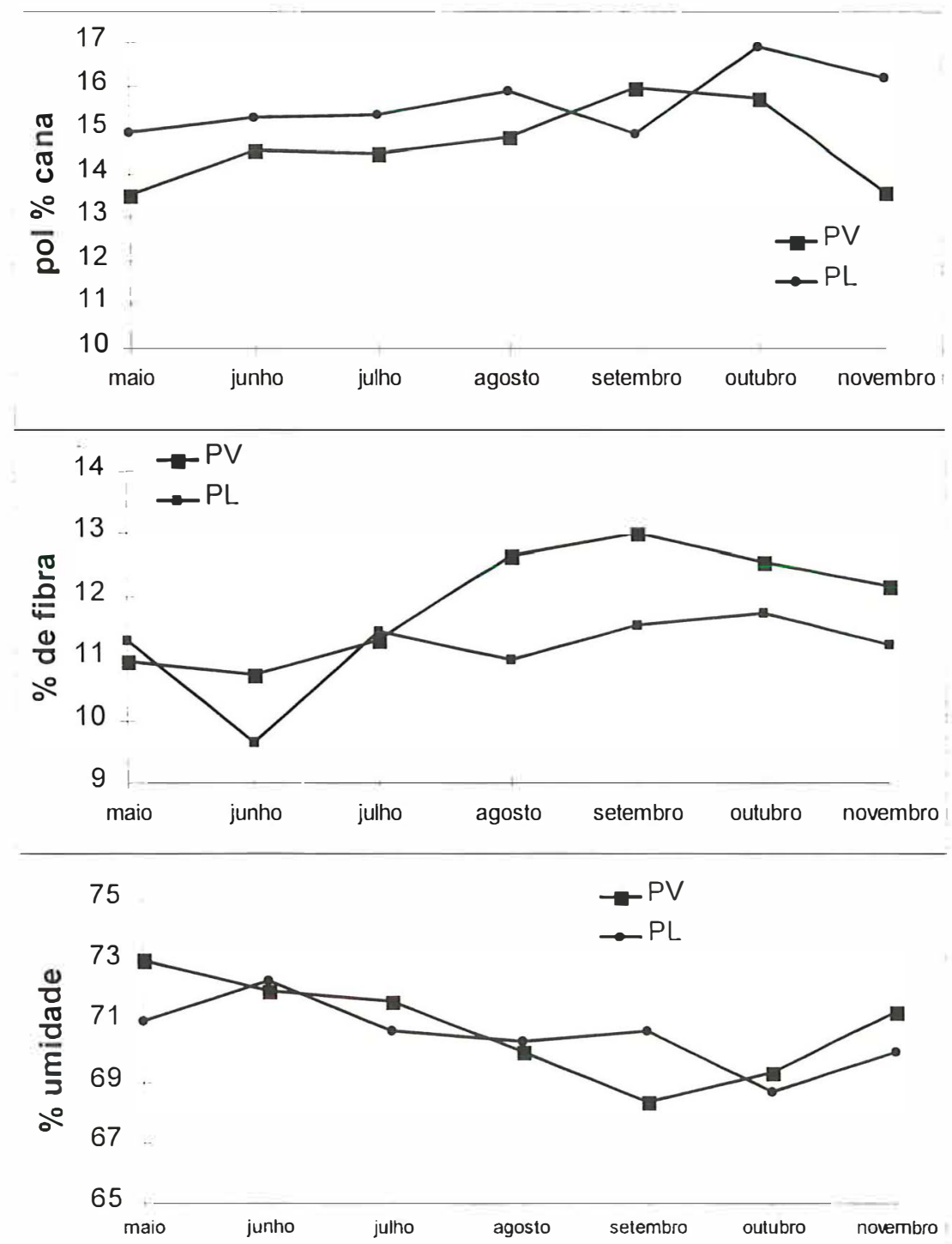

Figura 14. Características tecnológicas da cultivar RB855536

Nos primeiros meses a variação da curva da pol \% cana dessa cultivar foi praticamente constante nos dois solos, mostrando um comportamento semelhante. Em - todas as amostragens a cultivar apresentou valores da pol \% cana maiores que o mínimo recomendável para colheita nos dois solos, mostrando elevado potencial produtivo para as agroindústrias. Apesar de ser considerada como uma cultivar de maturação média, esta apresentou, no PL, os maiores valores em outubro (maturação tardia) (Figura 14). No mês de setembro, coincidindo com o valor mais alto da pol \% cana verificou-se o 
menor valor de umidade do colmo no PV e no PL temos um aumento da umidade do colmo associado à queda da pol \% cana, mostrando que este parâmetro sofre influência da umidade do colmo da cultivar, a qual deve estar relacionada à umidade do solo. No PL, a porcentagem de fibra da cultivar sempre mostrou-se baixa. No PV, isto ocorreu somente nos primeiros meses e depois atingiu os níveis ideais. Os valores de umidade do colmo foram muito próximos nos dois ambientes, indicando um grau de hidratação semelhante da planta. No mês de junho, no PL, temos aumento na umidade dos colmos e queda na porcentagem de fibra, porém o valor da pol \% cana continuou aumentando. Já no mês de setembro ocorreu um ligeiro aumento na umidade dos colmos e na porcentagem de fibra também, mas o valor da pol \% cana sofreu um decréscimo. Isso mostra que a mesma cultivar pode apresentar diferentes alterações nesses parâmetros em função das diferentes condições do meio de desenvolvimento.

A cultivar RB72454, no PV, apresentou curvas da pol \% cana e da porcentagem de fibra crescentes (Figura 15). Já a curva de umidade dos colmos apresentou comportamento decrescente, mostrando que neste ambiente com o passar do tempo a umidade dos colmos diminuiu e a porcentagem de sacarose e fibra aumentaram. não demonstrando interferências de possíveis alterações edafoclimáticas, manifestada em grandes variações nas características tecnológicas dessa cultivar de um período para outro, como ocorreu no PL (Figura 15). As variações observadas no PL mostraram comportamentos diferentes nos diversos meses de amostragem. Na Figura 15 verifica-se o comportamento das características tecnológicas da cultivar no PL. Nos meses iniciais as curvas da pol \% cana e de teor de fibra revelaram associação com a curva de unnidade dos colmos. Quando a umidade dos colmos diminuía ocorria um aumento no valor da pol \% cana e da porcentagem de fibra na cana-de-açúcar. Já no mês de outubro houve comportamento diferente. A queda na umidade dos colmos provocou aumento no valor da pol \% cana, porém a porcentagem de fibra também diminuiu em relação ao período anterior, o que caracteriza uma variação de comportamento neste ambiente em relação aos períodos anteriores. 

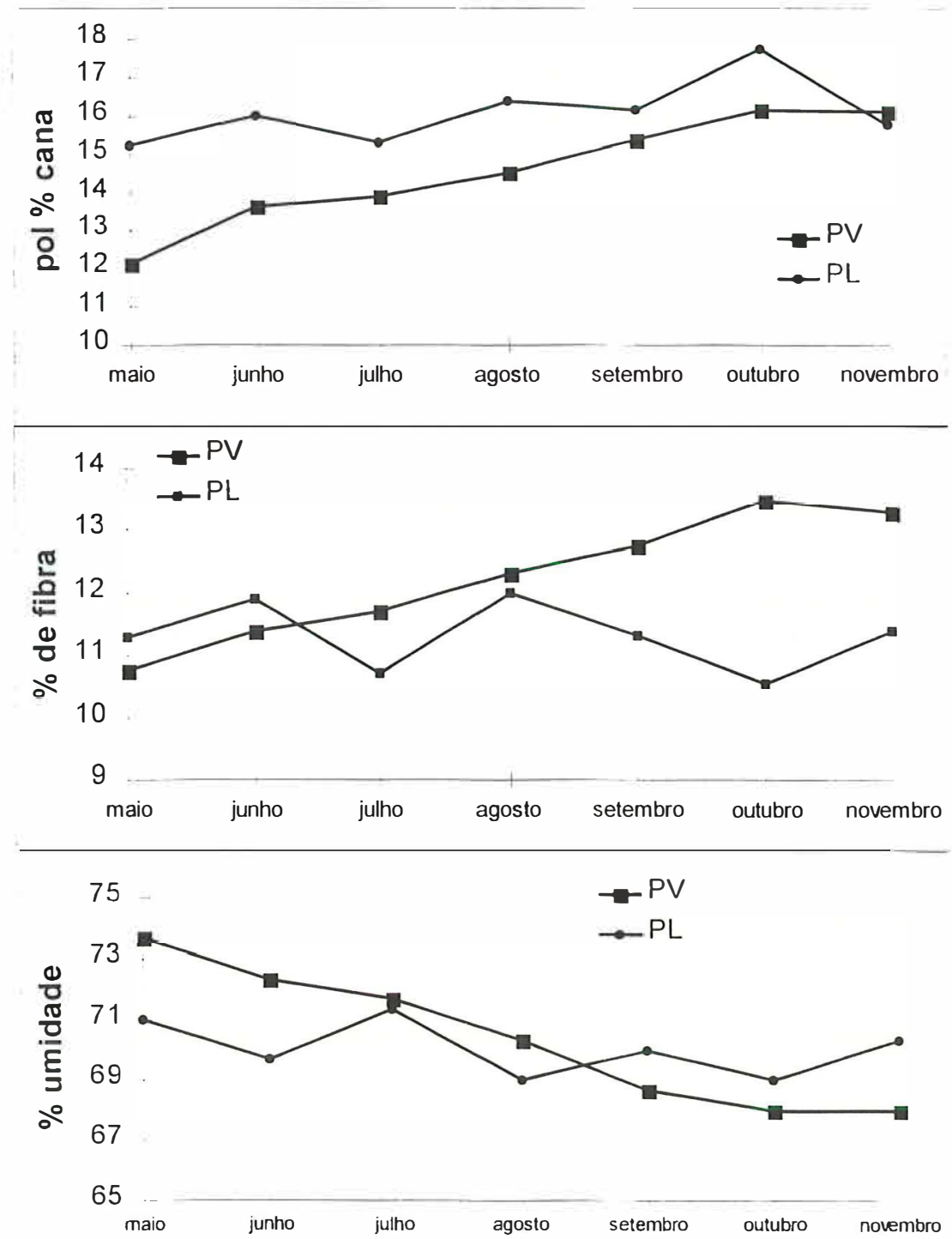

Figura 15. Características tecnológicas da cultivar RB72454

Os valores da pol \% cana da cultivar RB72 +54 sempre foram maiores no PL, mostrando que este ambiente promove melhores condições de armazenamento de sacarose para esta cultivar (Figura 15). A maior amplitude da pol \% cana entre os solos pode ser verificada nos meses iniciais. Como para outras cultivares, a porcentagem de fibra mostrou-se baixa no solo PL, principalmente nos meses de jullho e outubro. o que poderia prejudicar a produção de bagaço, que é utilizado como fonte de enerģia para a própria indústria. Esta cultivar apresentou maturação tardia nos dois solos. assim como 
ela é classificada pelo programa de melhoramento da instituição geradora.

Na Figura 16 estão as curvas das características tecnológicas referentes à cultivar RB835486.
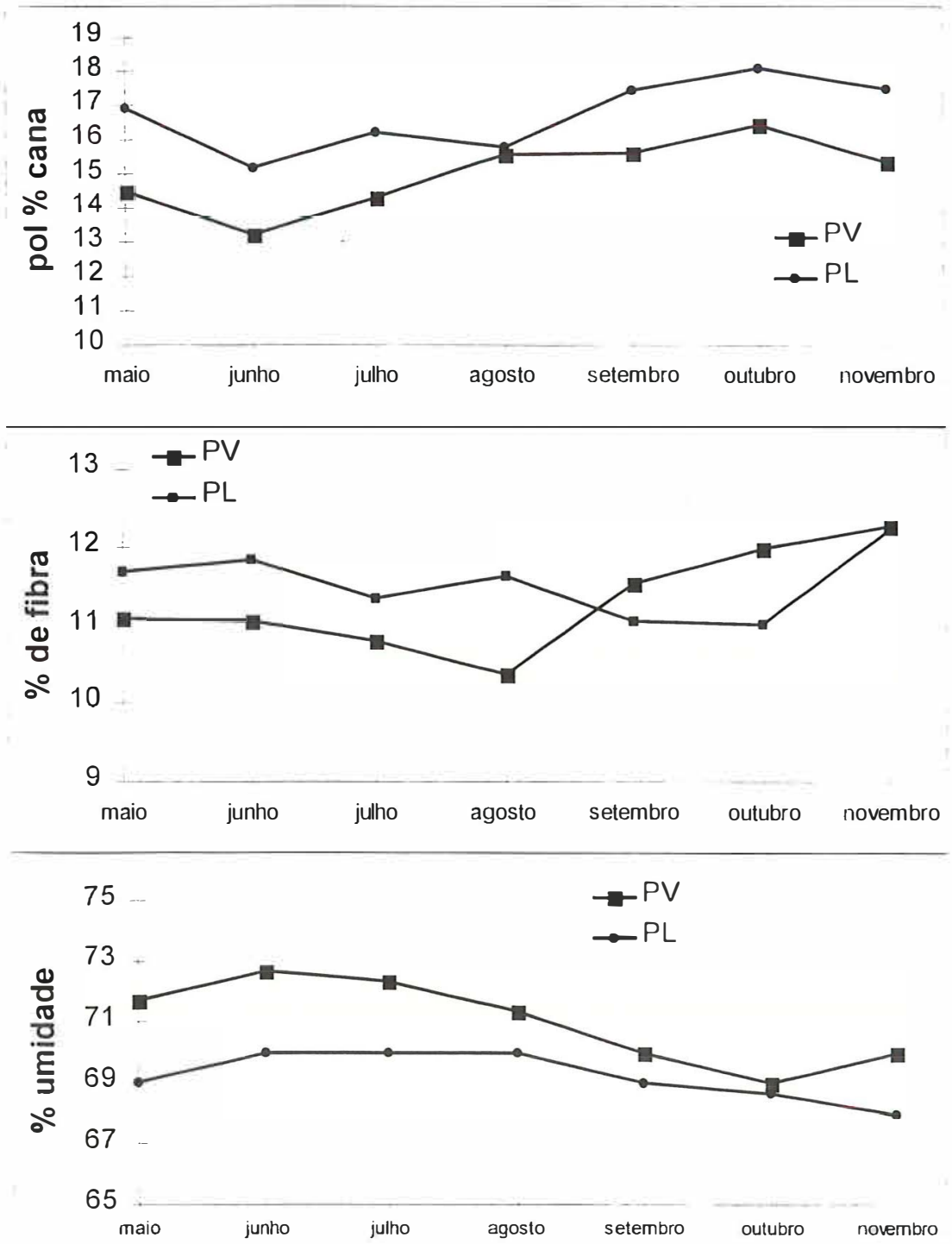

Figura 16. Características tecnológicas da cultivar RB835486

Na curva da pol \% cana podemos verificar que o maior valor foi obtido no mês de outubro nos dois solos, apesar de ser considerada uma cultivar precoce. Todas as amostragens revelaram valores da pol \% cana elevados nos dois solos, mostrando um 
bom potencial de acúmulo de sacarose para estes ambientes. Do mesmo modo que em outras cultivares desse estudo, no PL a curva da pol \% cana sempre apresentou valores maiores e os valores da umidade dos colmos foram sempre menores. No mês de agosto os valores da pol \% cana foram semelhantes nos dois solos, indicando uma queda no valor da pol \% cana do PL, a qual não foi relacionada com a umidade que foi praticamente constante e sim a um aumento na porcentagem de fibra. O comportamento das curvas da pol \% cana e da umidade dos colmos foi bastante semelhante nos dois solos e as curvas de porcentagem de fibra foram distintas, mostrando, neste parâmetro, grande influência do meio onde a cultura está instalada (Figura 16).

No PL a curva da pol \% cana da cultivar RB 855257 manteve uma certa estabilidade durante todo o período de colheita apresentando valores altos (Figura 17). Diferentemente, no PV começou com valores baixos da pol \% cana, que foram aumentando até o mês de julho. No período entre jullho e agosto ocorreu uma forte queda na porcentagem da pol. fato este que culminou com o aumento da umidade dos colmos. provavelmente ocasionado pelas chuvas do período. sendo esse mesmo efeito verificado na cultivar RB855113 nos dois solos (Figura 13). A cultivar retomou o crescimento da curva da pol \% cana no mês de setembro, mostrando uma estabilidade nos meses seguintes. De um modo geral, com exceção do mês de agosto, esta cultivar apresentou padrões semelhantes na : urva da pol \% cana nos dois solos, sendo cue as variações foram diferentes nos valores de umidade dos colmos e principalmente nos valores da porcentagem de fibra.

No PL, a RB845257 apresentou valores da pol \% cana elevados jai no início das amostragens, revelando grande acúmulo de sacarose (Figura 17). Este fato não ocorreu no PV, que só apresentou valores elevados nos meses finais de amostragem. Isto mostra o comportamento diferenciado de maturação nos dois ambientes. Nos dois solos a maturação foi tardia e não média como ela é classificada.

A umidade dos colmos da RB845257 tornou-se muito semellhante nos dois ambientes nos períodos finais de amostragem, mostrando que a mesma perdeu mais umidade ao longo do tempo no PV do que no PL, o qual já apresentou valores baixos de umidade dos colmos no início das amostragens (Figura 17). 


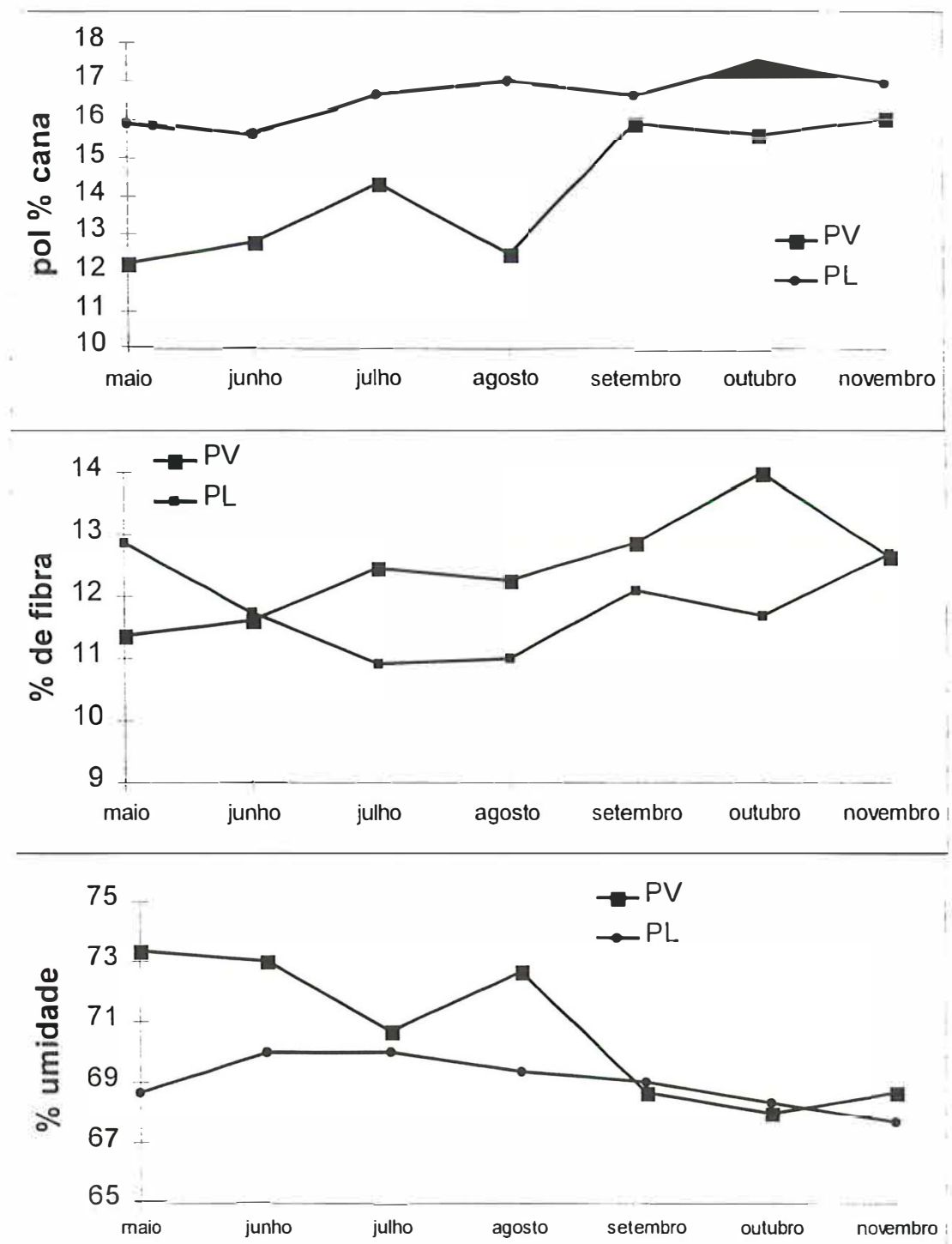

Figura 17. Características tecnológicas da cultivar RB845257

Na Figura 18 estão as características tecnológicas médias das cultivares para os dois solos. Podemos notar que na média as cultivares do PL sempre apresentaram valores da pol \% cana maiores, revelando que nas condições desse ano agrícola este solo apresentou melhores taxas de acúmulo de sacarose, devido à elevada saturação de água no solo. O mais interessante é o fato de a média geral de acúmulo de sacarose no PL apresentar valores da pol \% cana elevados já nos períodos inicias de safra, que 
geralmente é a época em que as agroindústrias recebem a matéria-prima com menor porcentagem de sacarose.

$\mathrm{Na}$ maioria dos periodos de amostragem a porcentagem de tibra mostrou-se menor no solo PL, e em certos períodos estes valores foram muito baixos, o que pode prejudicar o suprimento de bagaço para geração de energia dentro da agroindústria.

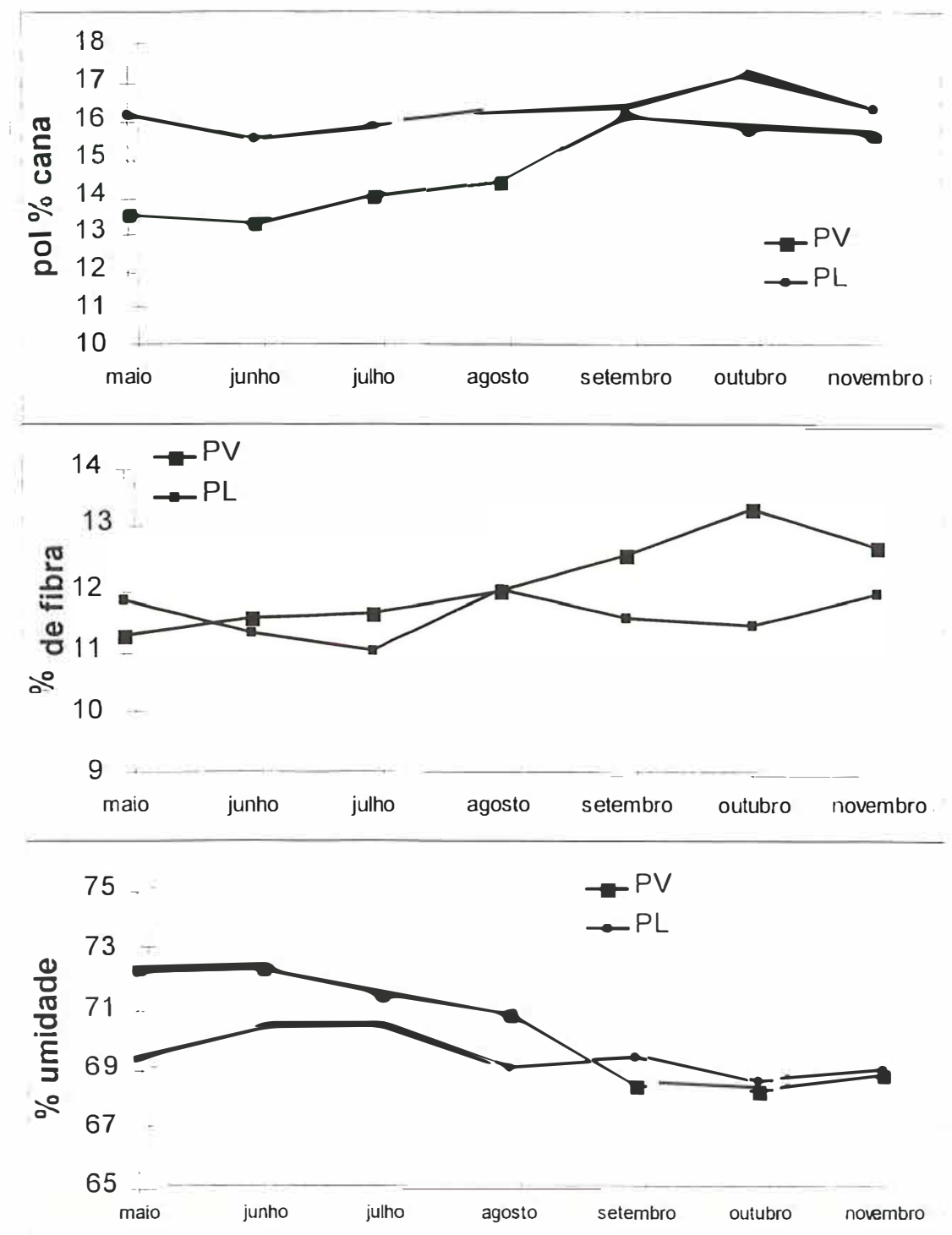

Figura 18. Características tecnológicas médias das cultivares 


\section{CONCLUSÕES}

- As cultivares de cana-de-açúcar estudadas neste trabalho apresentaram comportamento de produção agrícola diferente em função do ambiente de desenvolvimento.

- Os parâmetros de qualidade tecnológica avaliados neste trabalho apresentaram comportamentos variados de acordo com as cultivares de cana-de-açúcar e ambiente de cultivo. 


\section{REFERÊNCIAS BIBLIOGRÁFICAS}

ALEXANDER, A.G. Sugarcane physiology. New York: Elsevier, 1973. 752p.

ALLARD, R.W.; BRADSHAW, A.D. Implications of genotype-environmental interactions in applied plant breeding. Crop Science, v.4, p. 503-508, 1964.

ANUÁRIO ESTATÍSTICO DO BRASIL- 1996, v. 56, p.3-52, 1996.

BALIERO, J.M. Evolução do perfilhamento em três variedades comerciais de cana-deaçúcar (em função da época de corte). Álcool \& Açúcar, n.80, p.24-31, 1995.

BASSINELLO A.I. Apreciações sobre experimentos de competição de variedades da série 1972. Brasil Açucareiro, v. 5, n.87, p. 42-59, 1976.

BASSINELLO A.I. Interações de genótipos x ambientes em cana-de-açúcar. Piracicaba, 1984. 110p. Dissertação (Mestrado) - Escola Superior de Agricultura "Luiz de Queiroz", Universidade de São Paulo.

BASSINELLO A.I.; MATSUOKA, S.; MENDES, A.C. Variedades de cana-de-açúcar para o Estado de São Paulo. Boletim Técnico PLANALSUCAR, n.3, p.1-18, 1976. 
BEAUCLAIR, E.G. F. de. Relações entre algumas propriedades químicas do solo e a produtividade da cana-de-açúcar, através de regressão linear múltipla. Piracicaba, 1991. 90p. Dissertação (Mestrado) - Escola Superior de Agricultura "Luiz de Queiroz", Universidade de São Paulo.

BITTENCOURT, V. C. de; JOÃO, J. ; ClEMENTE, J.L.; CARMELlO, Q.A. C.; BEAUCLAIR, E. F. de Produtividade da cana-de-açúcar e suas relações com a fertilidade dos solos e manejo da cultura. STAB: Açúcar, Álcool e Subprodutos, v.9, n.2, p.10-14, 1990.

BUTLER, B.E. Assessing the soil factor in agricultural production. Journal of the Australian Agricultural Science, v. 30, p. 232-240, 1964.

CÂMARA, G.M.S. Cultura da cana-de-açúcar: introdução. Piracicaba: ESALQ, Departamento de Agricultura, 1996. 20p.

CAMARGO, O.A.; MONIZ, A.C.; JORGE. J.A.; VALADARES, J.M.A.S. Método de análise química, mineralógica e física dos solos do Instituto Agronômico de Campinas. Campinas: Instituto Agronômico, 1986. 93p. (IAC. Boletim Técnico, 106).

CENTRO DE TECNOLOGIA COPERSUCAR. Quarta geração de variedades de cana COPERSUCAR. Piracicaba, 1993. 16p. (COPERSUCAR. Boletim Técnico. Edição Especial)

CESAR, M.A.A.; DELGADO, A.A.; CAMARGO, A.P. de; BISSOLI, B.M.A.; SILVA, F.C. da. Capacidade de fosfatos naturais e artificiais em elevar o teor de fósforo no caldo de cana-de-açúcar (cana-planta), visando o processo industrial. STAB: Açúcar, Álcool e Subprodutos, v.6 n.2, p.32-38. 1987 a. 
CESAR, M.A.A.; DELGADO, A.A.; PEXE, C.A.; SILVA, F.C. da; BORGES, M.M. Estudo sobre diferentes técnicas e variadas combinações de adubação na cultura canavieira e seus efeitos na qualidade tecnológica do caldo. O Solo, v.79, n.1. p.69$77,1987 b$.

DIAS, F.L.F. Relação entre a produtividade, clima, solos e variedades de cana-deaçúcar, na Região Noroeste do Estado de São Paulo. Piracicaba, 1997. 64p. Dissertação (Mestrado) - Escola Superior de Agricultura "Luiz de Queiroz", Universidade de São Paulo.

DILLEWIJN, C. van. Botany of sugarcane. Walthham: Chronica Botanica, 1952. $371 \mathrm{p}$.

EMPRESA BRASILEIRA DE PESQUISA AGROPECUÁRIA. Serviço Nacional de Levantamento e Conservação de Solos. Normas e critérios para levantamentos pedológicos. Rio de Janeiro, 1989. 94p.

FAUCONNIER, R.; BASSEREAU, D. La caña de azucar: técnicas agricolas y producciones tropicales. Barcelona: Blume, 1975. 433p.

FAVARIN, J.L. Atributos químicos e físicos de solos de uma topossequência influenciando o desenvolvimento radicular e o rendimento da cana-de-açúcar (Saccharum spp. L.). Piracicaba, 1995. 98p. Tese (Doutorado) - Escola Superior de Agricultura "Luiz de Queiroz", Universidade de São Paulo.

FERNANDES, A.C. Terceira geração de variedades de cana COPERSUCAR. São Paulo, 1991. 27p. (COPERSUCAR. Boletim Técnico. Edição Especial).

FERNANDES. A.J. Manual da cana-de-açúcar. Piracicaba: Livroceres, 1984. 196p. 
FERNANDES, J. População de colmos na cultura de cana-de-açúcar. Álcool \& Açúcar, v.6, p.38-46, 1986.

HERMANN, H.T.; YANG S.J. Efecto de la disponibilidad de humedad del suelo sobre el cultivo de la caña de azucar. Acta Agronomica, v.37, p. 19-35, 1987.

HUMBREIT,R.P. The growing of sugar cane. New York: Elsevier, 1968. 779p.

JOAQUIM, A.C.; BELLINASO, I.F.; DONZELLI, J.L.; QUADROS, A.D. de; BARATA, M.Q.S. Potencial e manejo de solos cultivados com cana-de-açúcar. In: SEMINÁRIO DE TECNOLOGIA AGRONÔMICA 6., Piracicaba, 1994. Anais. Piracicaba: COPERSUCAR, 1994. p.1-10.

LEPSCH, I.F. Influência dos fatores edáficos na produção. In: CASTRO, P.R.C.; FERREIRA, S.O.; YAMADA, T. (Coord.) Ecofisiologia da produção. Piracicaba: Associação Brasileira para Pesquisa da Potassa e do Fosfato, 1987. p. 83-98.

LO, C.C. Sugarcane breeding for different enviroments. In: COPERSUCAR INTERNATIONAL SUGARCANE BREEDING WORKSHOP. Piracicaba. 1987. Anais. Piracicaba: COPERSUCAR, 1987. p. 189-202.

LUCCHESI, A.A. Processos fisiológicos da cultura da cana-de-açúcar (Saccharum spp). Boletim Técnico ESALQ/CENA, n. 7, p.1-50, 1995.

MACHADO, F.C. Fisiologia da produção de cana-de-açúcar. In: PARANHOS, S.B. (Coord.) Cana-de-açúcar: cultivo e utilização. Campinas: Fundação Cargill, 1987. v.1, p. 56-87. 
MAGALHÃES A.C.N. Ecofisiologia da cana-de-açúcar: aspectos do metabolismo do carbono na planta. In: CASTRO, P.R.C.; FERREIRA, S.O.; YAMADA, T. (Coord.) Ecofisiologia da produção. Piracicaba: Associação Brasileira para Pesquisa da Potassa e do Fosfato, 1987. p. 113-118.

MALAVOLTA, E.; VITTI, G.C.; OLIVEIRA, S.A. Avaliação do estado nutricional das plantas: princípios e aplicações. Piracicaba: Associação Brasileira para Pesquisa da Potassa e do Fosfato, 1997. cap.6, p.231-307: Metodologia para análise de elementos em material vegetal.

McINTOSH, M.S. Analysis of combined experiments. Agronomy Journal, v.75, p.153-155, 1983.

NUNES JUNIOR, D.; MACHADO JUNIOR., G.R. Metodologia para avaliação do comportamento agro-tecnológico de novos híbridos de cana-de-açúcar Boletim Técnico COPERSUCAR, v.15, p. 11-17, 1981.

NUNES JUNIOR., D.; SCHOUCHANA, F. Determinação do valor econômico de variedade de cana-de-açúcar em função das épocas de corte e das distâncias da usina. Boletim Técnico COPERSUCAR, v.25, p. 2-10. 1984.

NUNES JUNIOR., D.: PINTO, R.S. A. de; KIL, R.A. Indicadores de desempenho da agroindústria canavieira. Ribeirão Preto: Instituto de Desenvolvimento Agroindustrial, 1998. 119p.

OLIVEIRA, J.B. de; JACOMINE, P.K.T.; CAMARGO, M.N. Classes gerais de solos do Brasil: guia auxiliar para seu reconhecimento. Jaboticabal: UNESP. 1992. 201p. 
ORLANDO FILHO, J.; HAAG, H.P.; ZAMBELlO JUNIOR, E. Crescimento e absorção de macronutrientes pela cana-de-açúcar, variedade CB41-76, em função da idade, em solos do Estado de São Paulo. Boletim Técnico PLANALSUCAR, v.2, n.1, p.3-127, 1980.

PIRES, C.E.L.S. Estabilidade fenotípica de variedades de cana-de-açúcar (Saccharum spp.) nos Estados de Pernambuco e Rio Grande do Norte. Piracicaba, 1981. 72p. Dissertação (Mestrado) - Escola Superior de Agricultura "Luiz de Queiroz", Universidade de São Paulo.

POLLOCK, J.S. Variety $\mathrm{x}$ environmental interactions. In: CONFERENCE OF THE QUEENSLAND SOCIETY OF SUGAR CANE TECHNOLOGISTS 45., Lowsville, 1978. Proceedings. p. 273-277.

PRADO, A.P. A. Perfilhamento e produção da cana-de-açúcar em função da densidade de plantio. Piracicaba, 1988. 80p. Dissertação (Mestrado) - Escola Superior de Agricultura "Luiz de Queiroz", Universidade de São Paulo.

PRADO, H.; ROSSETTO, R.; LANDELL. M.G.A. IAC propõe classificação de solos adaptada para a cana-de-açúcar. STAB: Açúcar, Álcool e Subprodutos, v.16 n.3, p.13. 1998 .

RAIJ, B. van; QUAGGIO, J.A. Métodos de análise de solo para fins de fertilidade. Campinas: Instituto Agronômico, 1983. 31p.

RAIZER, A.J. Interações genótipos x ambientes e estabilidade fenotípica em cana-deaçúcar no Estado de São Paulo. Piracicaba, 1998. 103p. Dissertação (Mestrado) Escola Superior de Agricultura "Luiz de Queiroz”. Universidade de São Paulo. 
REICHARDT, K. Dinâmica da matéria e da energia em ecossistemas. Piracicaba: ESALQ, Depto. Física e Metereologia, 1996. 513p.

RIBEIRO, M.R.; HALSTEATED, E.H.; JONG, E. DE Rendimento da cana-de-açúcar e características das terras da microregião da mata norte de Pernambuco. Revista Brasileira de Ciência do Solo, v. 8, p. 209-213, 1984.

RICHARDS, L.A. Diagnoses and improvement of saline and alkai soil. Washington: USDA, 1954. (Agricultural Handbook, 60)

RITCHEY, K.D.; SILVA, J.E.; ESPINOZA W.; LOBATO, E. Downward movement of calcium and the improvement of subsoil rooting in oxisols of Brazil. In: RUSSEL, S.; IGUE, K.; MEHTA. Y.R. (Coord.) The soil/root system in relation to Brazilian agriculture. Londrina: IAPAR, 1981. p.137-153.

SÃO PAULO. Secretaria de Agricultura e Abastecimento. LUPA (Levantamento Censitário de Unidades de Produção Agrícola). São Paulo, 1987. 4v.

SILVA, G.M. A. Influência da adubação na qualidade da cana-de-açúcar. In: ORLANDO FILHO, J. (Coord.) Nutrição e adubação da cana-de-açúcar no Brasil. Piracicaba: PLANALSUCAR, 1983. v.2, p.317-334.

SILVA, L.C.F. da; CASAGRANDE, J.C. Nutrição mineral da cana-de-açúcar - (macronutrientes). In: ORLANDO FILHO, J. (Coord.) Nutrição e adubação da cana-de-açúcar no Brasil. Piracicaba: PLANALSUCAR, 1983. v.2, p.317-334.

STUPIELLO, J.P. A cana-de-açúcar como matéria-prima. In: PARANHOS. S.B. (Coord.) Cana-de-açúcar: cultivo e utilização. Campinas: Fundação Cargill. 1987. v.2, p. 761-804. 
TANIMOTO, T. The press method of cane analyses. Hawaiian Planter's Recorder, v.57, p.133-50, 1964.

UNIVERSIDADE FEDERAL DE SÃO CARLOS. Centro de Ciências Agrárias. Programa de melhoramento genético da cana-de-açúcar. http://www.dbv.cca.ufscar.br/pmgca. (18 ago. 1999).

VITTI, G.C. Avaliação e interpretação do enxofre no solo e na planta. Jaboticabal: UNESP, 1988. 37p. 